BNL 50828

\title{
THE BROOKHAVEN BUILDINGS ENERGY CONSERVATION OPTIMIZATION MODEL
}

Steven C. Carhart, Shirish S. Mulherkar, and Yasuko Sanborn

January 1978

Prepared for the

DIVISION OF BUILDINGS AND COMMUNITY SYSTEMS

UNITED STATES DEPARTMENT OF ENERGY

by the

ECONOMIC ANALYSIS DIVISION

DEPARTMENT OF ENERGY AND ENVIRONMENT

BROOKHAVEN NATIONAL LABORATORY

ASSOCIATED UNIVERSITIES, INC.

UNDER CONTRACT NO. EY-76-C-02-0016 WITH THE

UNITED STATES DEPARTMENT OF ENERGY 


\section{DISCLAIMER}

This report was prepared as an account of work sponsored by an agency of the United States Government. Neither the United States Government nor any agency Thereof, nor any of their employees, makes any warranty, express or implied, or assumes any legal liability or responsibility for the accuracy, completeness, or usefulness of any information, apparatus, product, or process disclosed, or represents that its use would not infringe privately owned rights. Reference herein to any specific commercial product, process, or service by trade name, trademark, manufacturer, or otherwise does not necessarily constitute or imply its endorsement, recommendation, or favoring by the United States Government or any agency thereof. The views and opinions of authors expressed herein do not necessarily state or reflect those of the United States Government or any agency thereof. 


\section{DISCLAIMER}

Portions of this document may be illegible in electronic image products. Images are produced from the best available original document. 


\section{THE BROOKHAVEN BUILDINGS ENERGY CONSERVATION OPTIMIZATION MODEL}

Steven C. Carhart, Shirish S. Mulherkar, and Yasuko Sanborn

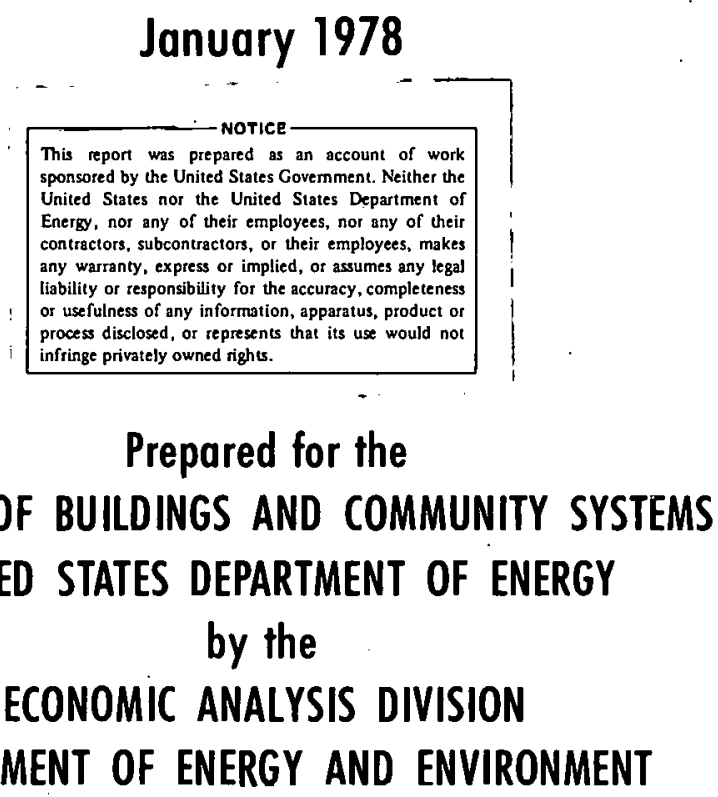

BROOKHAVEN NATIONAL LABORATORY

UPTON, NEW YORK 11973 
NOT I CE

This report was prepared as an account of work sponsored by the United States Government. Neither the United States nor the United States Department of Energy (DOE), nor any of their employees, nor any of their contractors, subcontractors, or their employees, makes any warranty, express or implied, or assumes any legal liability or responsibility for the accuracy, completeness or usefulness of any information, apparatus, product or process disclosed, or represents that its use would not infringe privately owned rights.

Printed in the United States of America

Available from

National Technical Information Service

U.S. Department of Commerce

- 5285 Port Royal Road

. : : Price:'Printed Copy $\$ 6.00 ;$ Microfiche $\$ 3.00$

October 1978

475 copies 


\section{ABSTRACT}

The Brookhaven Buildings Energy Conservation Optimization Model is a linear programming representation of energy use in buildings. Starting with engineering and economic data on cost and performance of energy technologies used in buildings, including both conversion devices (such as heat pumps) and structural improvements, the model constructs alternative flows for energy through the technologies to meet demands for space heating, air conditioning, thermal applications, and electric lighting and appliances. Alternative paths have different costs and efficiencies. Within constraints such as total demand for energy services, retirement of existing buildings, seasonal operation of certain devices, and others, the model calculates an optimal configuration of energy technologies in buildings.

The penetration of the various basic technologies within this configuration is specified in considerable detail, covering new and retrofit markets for nine building types in four regions. Each market may choose from several appropriate conversion devices and four levels each of new and retrofit structural improvement.

The principal applications for which the model was designed include the following: market penetration anaylsis, showing the role of individual technologies within a system context; policy analysis, to show the effect of buildings sector policies on the technologies in the building stock; analysis of RD\&D programs; analysis of the preferred configuration for sensitivity to changes in price or other variables; analysis of the effect of technology implementation rates on overall energy; and the environmental and supply system effects of buildings energy conservation. 


\section{THIS PAGE \\ WAS INTENTIONALLY \\ LEFT BLANK}


CONTENTS

Abstract..................... ii

1. Tntroduction.................. 1

2. Structure of BECOM.............. 4

2.1. Mathematical structure......... 4

2.2. Economic Structure.......... 15

2.3. Structure of the Equations...... 17

3. Data Inputs................... 22

4. Model Operation and Outputs.......... 23

5. Applications................... 53

Acknowledgements................. 57

References..................... 58

Appendix A: Residential and Commercial

Inventory and Forecasts..... 59

Appendix B: Theoretical Loads for

Buildings............. 65

Conservation Technology Costs

and savings............. 70

First Costs of Conventional

HVAC Equipment.......... 79 


\section{Introduction}

The Brookhaven Buildings Energy Conservation Optimization Model (BECOM) is designed to provide a tool for projecting, analyzing, and evaluating the energy implications of conventional and proposed energy-related technologies in buildings. starting with detailed cost and performance data for individual building technologies, the model assembles alternative combinations of these technologies within a linear programming framework. For any combination of building stocks, fuel prices and availabilities, and other constraints on technological availability, BECOM calculates the preferred technological configuration of the buildings sector. Because the basic elements of the model are specified in terms of technologies, this configuration is expressed in terms of levels of market penetration of specific technologies. BECOM is designed as an extension of the Brookhaven Energy System Optimization Model (BESOM).

BESOM is a representation of the technological and economic features of the energy system. It has been used for detailed analyses of energy resource allocation and technology implementation. ${ }^{1}$ BESOM is a linear programming formulation of the Reference Energy System (RES). The RES, shown in Figure 1 , is a specialized format for representing the detailed technological structure of the energy system. Solution of the BESOM model yields resource consumption, energy flows through the RES network, and emissions to air and water. Efficiency, cost, and environmental data are supplied by the Energy Model Data Base. 2;3 Each flow through the network represents a process 


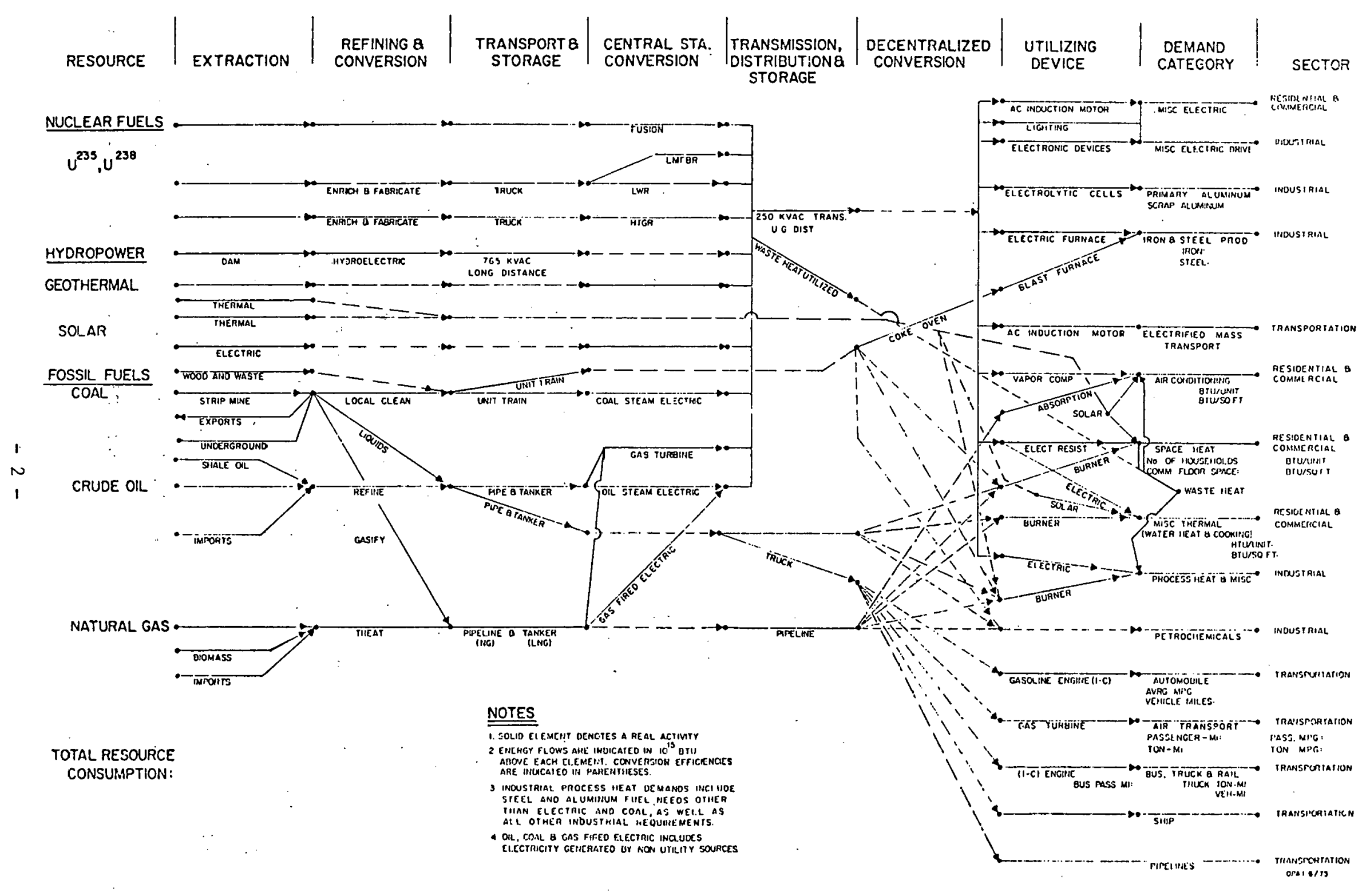

Figure 1. Reference energy system, year. 
or mix of processes to convert some primary resource into a fuel to meet some end use. Demand is specified by a specially defined term - the basic energy demand - which is the amount of energy required to support an energy-utilizing activity such as space heat, automotive propulsion, etc., at some nominal level (assuming no changes in equipment operation or user behavior). For a given basic energy demand, all other levels in a particular model run of energy flows are characterized as changes in technical demand efficiency. Basic energy demands are converted to fuel requirements by adjusting for demand conversion efficiencies, and fuel requirements are converted to primary resource demands by adjusting via appropriate supply conversion efficiencies. This generates the fuel $\mathrm{mix}$ and the primary resource mix.

Though BESOM contains a detailed representation of the supply system, it has a highly aggregated representation of the demand portion of the system. The methodology for extension of this approach for energy utilization technology has been described eisewhere 4 and is carried out in detail in the Buildings Energy Conservation Optimization Model (BECOM). BECOM extends BESOM to provide more end-use detail for residential and commercial buildings, explicitly modeling 25 energy conversion technologies and 8 structural technologies that can be used by 9 building types in each of 4 regions. The model covers all energy use in buildings including space heat, air conditioning, water heating, cooking, and appliance and illumination loads. As a result it is possible to measure in 
detail the effects of technical changes in burners, motors, and other conversion devices* and in structural shells as well as the effects of governmental programs such as setting standards for building insulation and appliance efficiency. BECOM thus allows an explicit and flexible formulation of the policy variables that the decision maker wishes to analyze. For a given set of inputs, the linear programming algorithm implements the lowest-cost technology in a particular market to the maximum level set by constraints. This decision can be made on the basis of very small cost differentials between technologies. Thus, technology implementation levels should be interpreted with care. However, this difficulty inherent in linear programming is mitigated in BECOM by the use of 72 separate building markets, which may be further subdivided by market share constraints.

\section{Structure of BECOM}

\subsection{Mathematical structure}

Mathematically the model is formulated as a modified transportation/transshipment problem. A transportation problem is concerned with distributing a commodity from any group of supply centers (sources) to any group of demand points (destinations), subject to limitations imposed by supply, demand, and other constraints. Each supply point $i(i=1,2, \ldots, m)$

*To simplify the exposition, the set of end-use energy conversion devices used in buildings by households, government activities, and commercial enterprises will be called conversion devices. This includes burners, heat pumps, electric motors, condensers, light bulbs and other illuminating equipment, blower fans; etc.; 
has a supply of $\mathrm{S}_{i}$ units to distribute to any destination $j(j=1,2, \ldots, n)$, each of which has a demand for $D_{j}$ units to be received from the sources. Assuming that the cost of distributing units from source $i$ to destination $j$ is proportional to the number of units shipped, the objective is to meet demands at all destinations at minimum.cost.

The problem then becomes

$$
\text { Minimize } z=\sum_{i=1}^{m} \sum_{j=1}^{n} c_{i j} x_{i j}
$$

where $z$ is the total distribution cost; $C_{i j}$ is the cost of shipping each unit from source $i$ to destination $j$; and $x_{i j}$ is the number of units shipped from $i$ to $j$. Since the total number of units shipped from source $i$ cannot be greater than the supply available, and since the demand at each destination has to be met, the constraints given below are introduced. Supply constraint:

$$
\sum_{j=1}^{n} a_{i j} x_{i j} \leq s_{i} \quad \text { for } i=1,2, \ldots, m
$$

Demand constraint:

$$
\sum_{i=1}^{m} b_{i j} x_{i j}=D_{j} \quad \text { for } j=1,2, \ldots, n
$$

Also:

$$
x_{i j} \geq 0 \quad \text { for all } i \text { and } j
$$

Here, $a_{i j}$ and $b_{i j}$ are the supply and demand efficiencies, respectively, for the fuel $x_{i j}$.

Besides the supply and demand constraints, there are various equations which reflect technological realities and market 
behavior. These are treated in more detail in section 2.3. BESOM is basically a modified transportation problem where the $x_{i j}$ 's represent the flow of energy (in $10^{1.5} \mathrm{Btu}$ ) from a resource to a demand at point of use. Each branch can be divided into two parts: a supply trajectory describiny the conversion of a resource into an intermediate energy form (such as elcctricity or distillate oil delivered to the home) and a demand trajectory including all further processes on the branch. There are now 27 supply and 22 demand categories.

The structure of BECOM is similar to that of a transshipment problem, with the aggregate demand points from BESOM for residential/commercial space heat, air conditioning, water heating, and appliances serving as sources for the transshipmen.t.

The destinations for this problem are the different buildings markets, each of which requires a certain amount of . energy to provide an acceptable level of comfort or service. Shipments from sources to destinations are made through intermediate transfer points or transshipment points, which in this case are conversion devices and thermal shells.

BESOM

Demand point

0

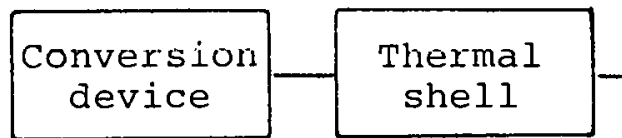

Building type

BECOM Demand point

BECOM Supply point

Each conversion device is characterized by an efficiency coefficient representing the efficiency of conversion of the fuel in the device and a cost coefficient which is the annual- 
ized capital cost for the device. Devices in existing buildings have a cost coefficient of zero since they are already in place. The thermal shell* is similarly characterized by an efficiency coefficient which compares its heat-loss characteristics with those of a defined reference shell, and by a cost coefficient which is the annualized capital cost of upgrading a structure relative to the reference shell. Non-upgraded buildings and reference new buildings have an efficiency of 1. Upgraded shells have higher efficiencies. The energy demand in each market can be met by any combination of firing device and thermal shell (represented schematically in Figures 2 to 7 ).

If the model is run as a cost minimization, it selects those combinations of conversion devices and thermal integrities that will satisfy demands in the various markets subject to the limitations imposed by the other constraints.

The operation of the modol may be illustrated by following one example in the diagram for residential space heat. In the "fuel" column in Figure 2 all the BESOM gas to space heat variables are gathered in a pool to serve as the gas source for. heating residential and commercial buildings. The gas or other fuel goes to two demand points: the detailed flow network representing technologies in buildings in one particular region, and an aggregated demand representing demand in the other three

*The shell is a level of energy integrity. For space heating and air conditiong, the shell corresponds to the building envelope; for water heating it can be interpreted to be the pipe and heater insulation; and for the appliance sector it is a representation of performance of improved appliance package. 


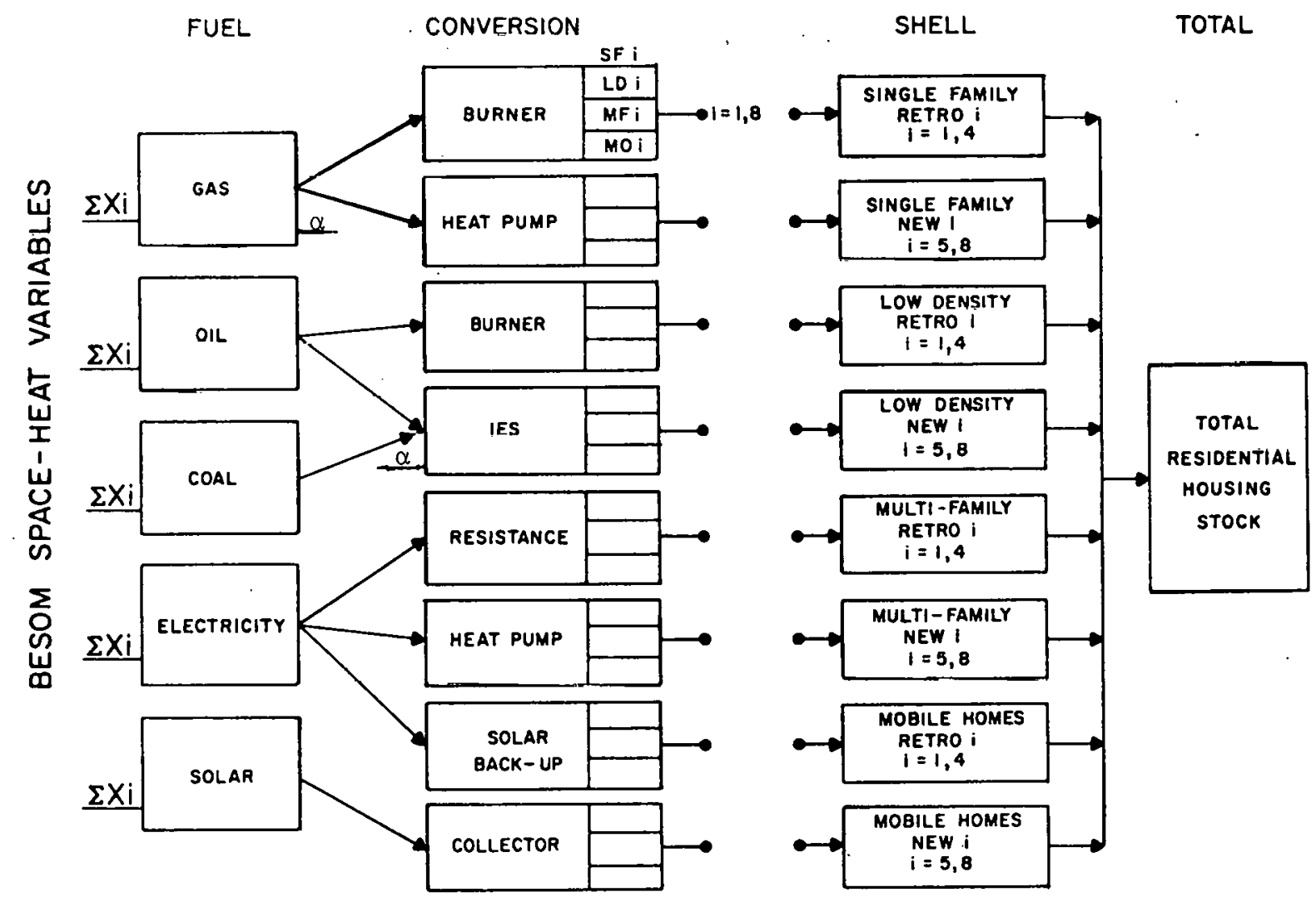

Figure 2. BECOM: Structure of residential space heat. 


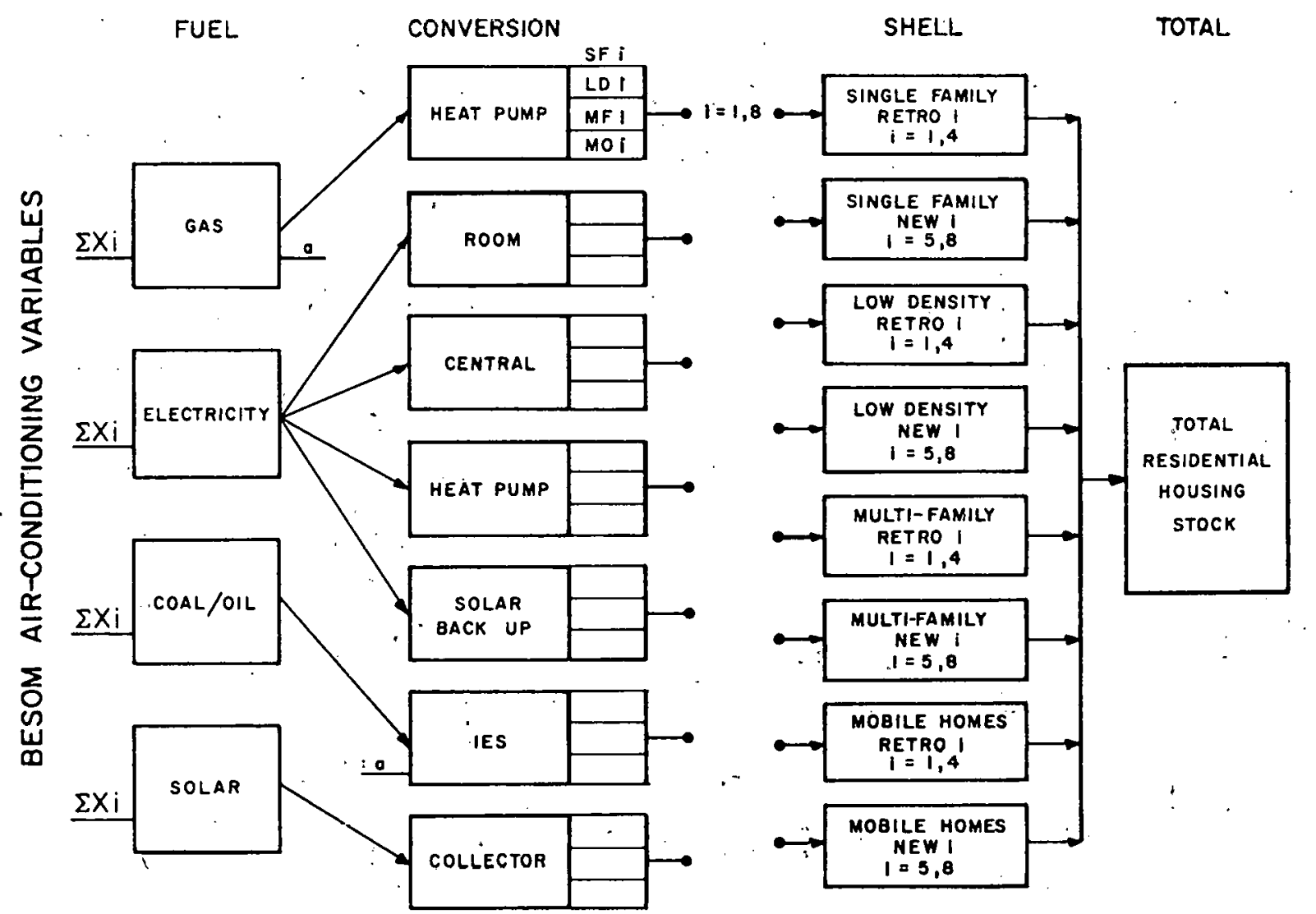

Figure 3. BECOM: Structure of residential air conditioning. 


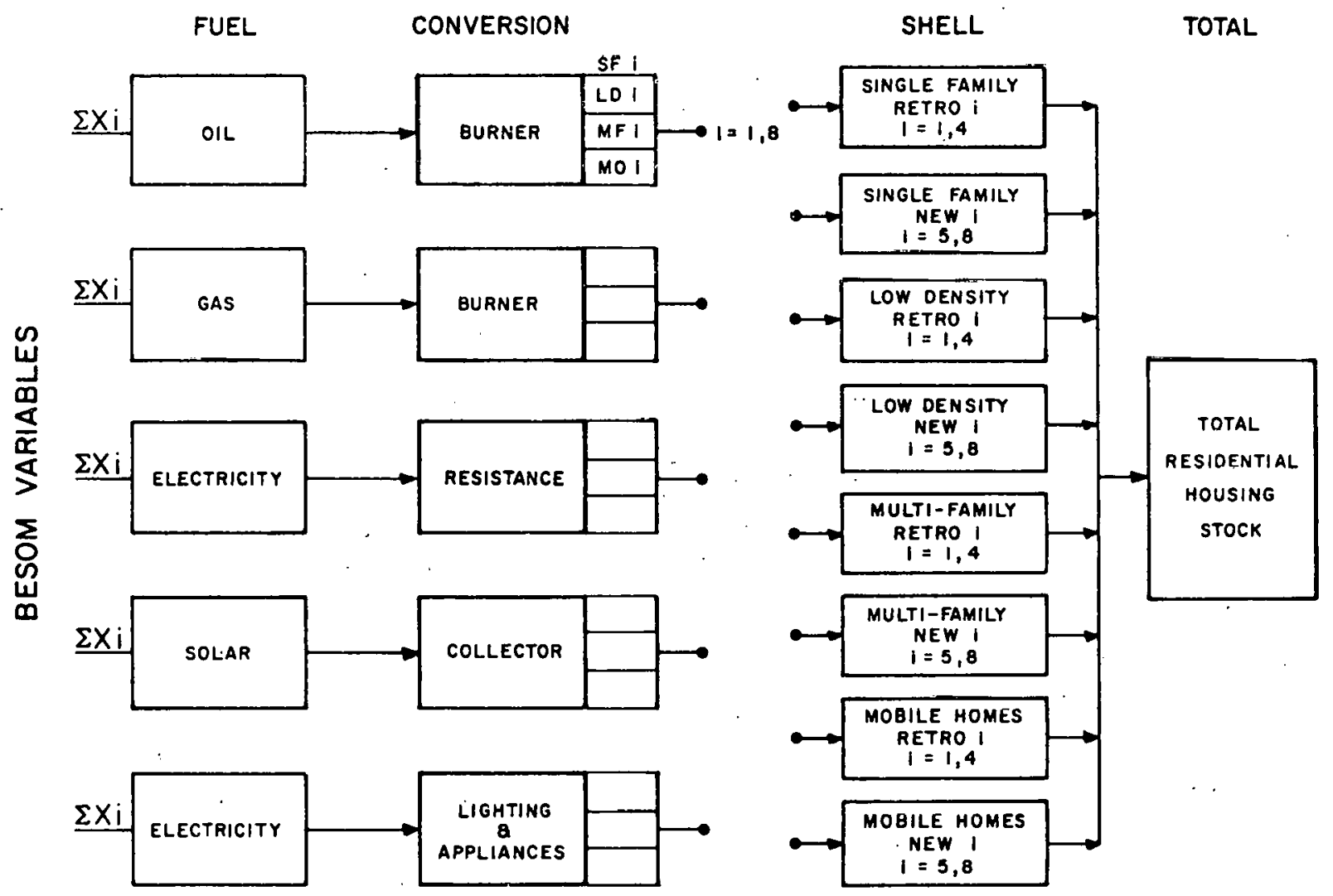

Figure 4. Structure of residential therma1, lighting and appliances. 


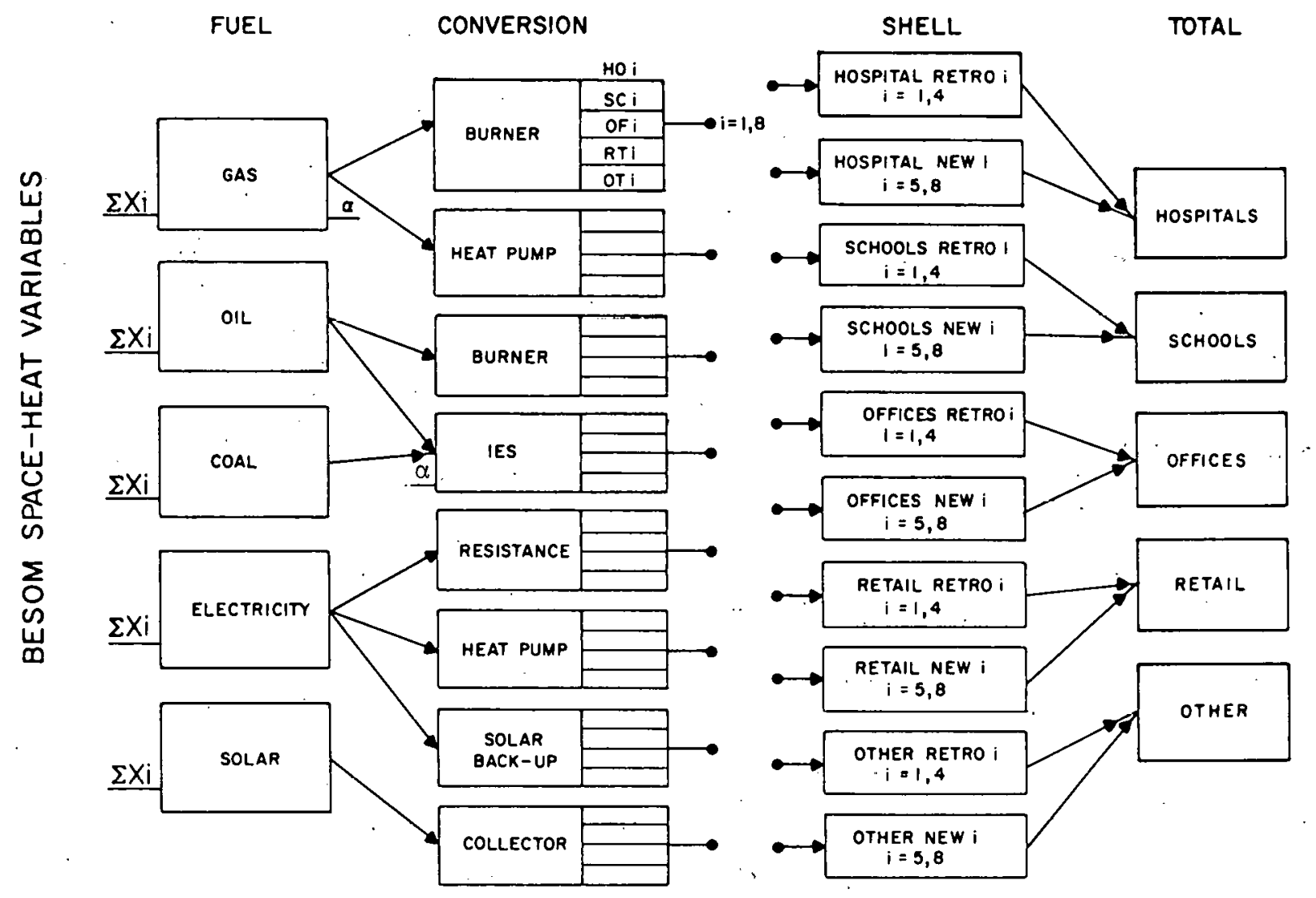

Figure 5. BECOM: Structure of commercial space heat. 


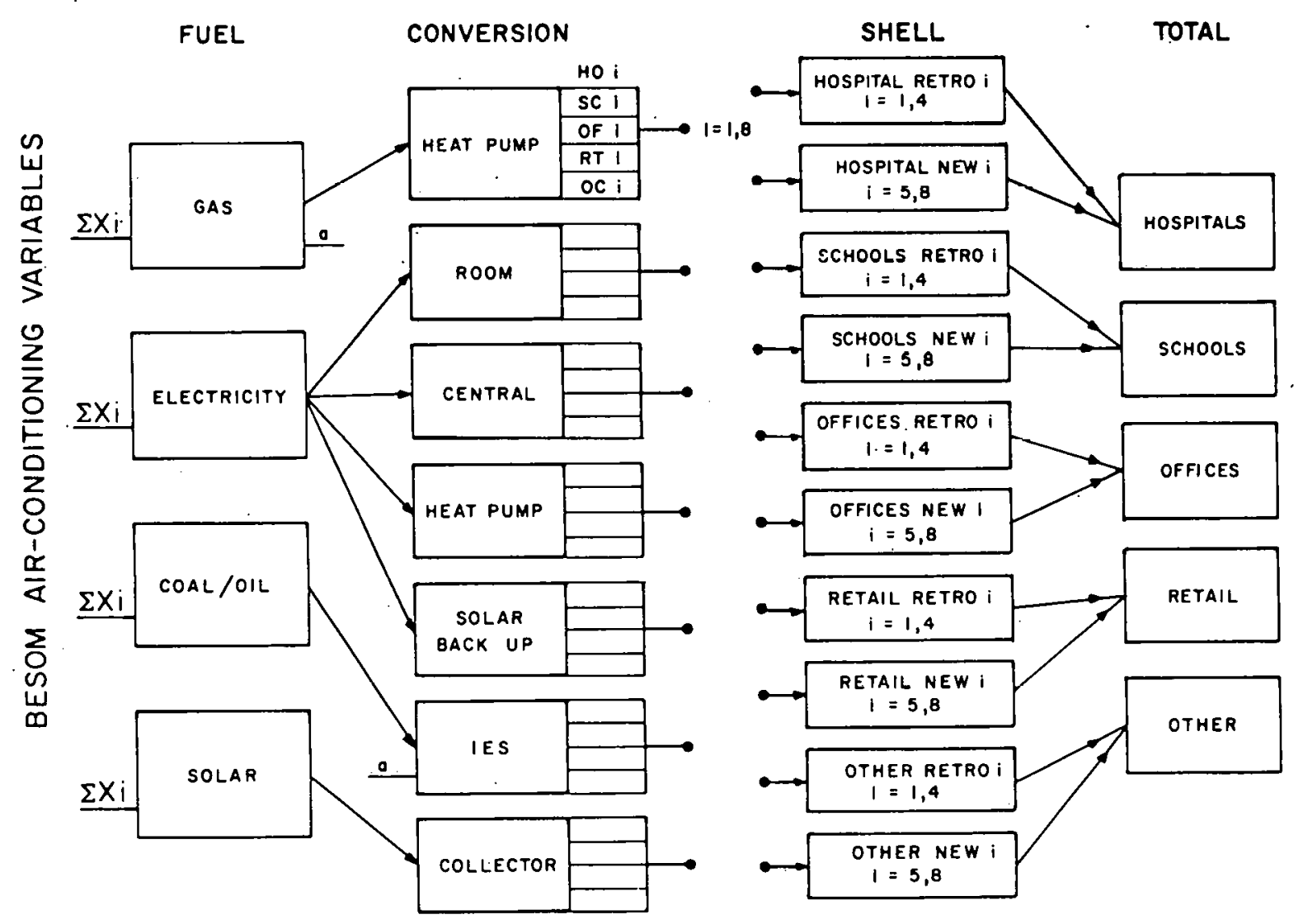

Figure 6. BECOM: Structure of commercial air conditioning. 


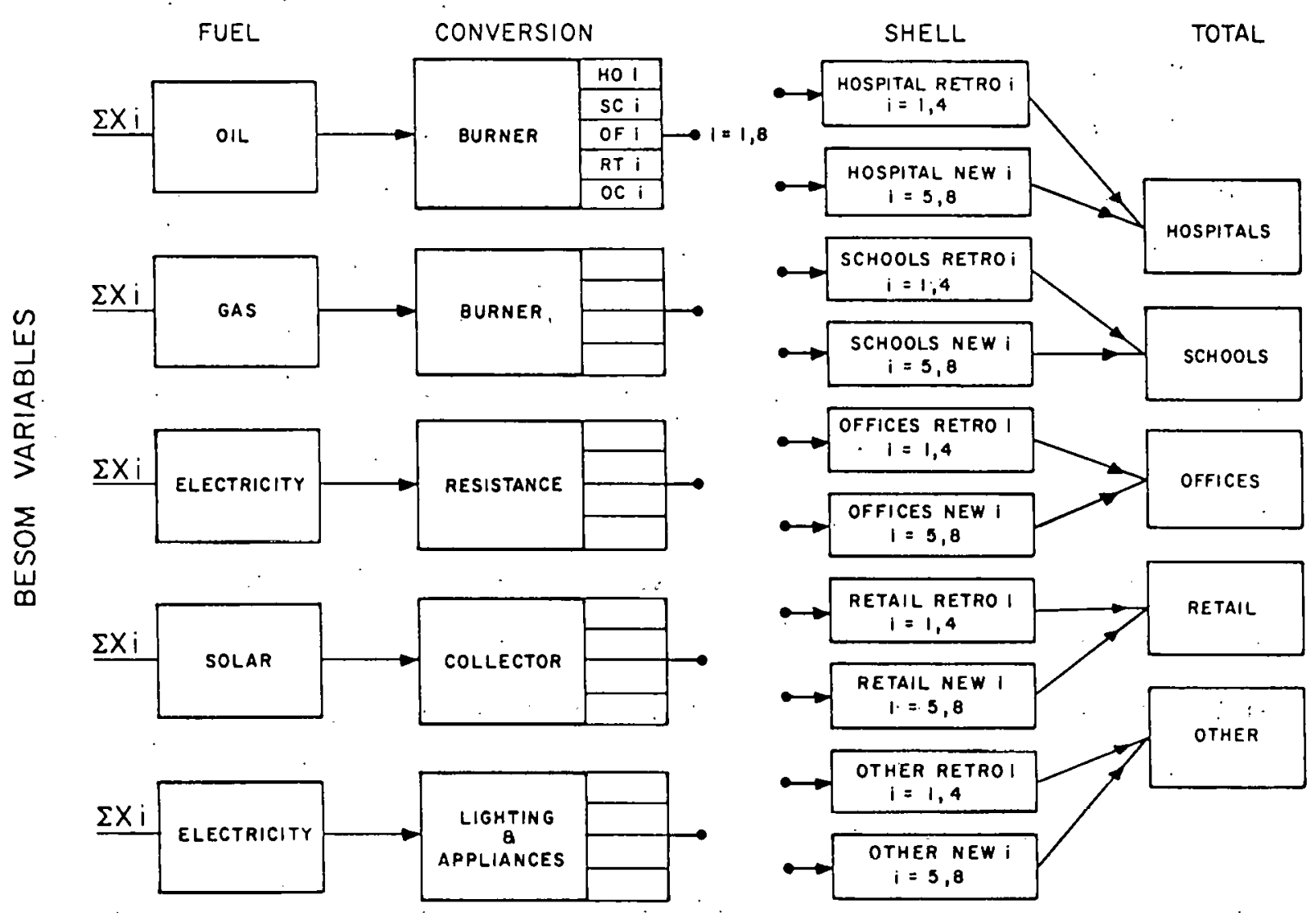

Figure 7. Structure of BECOM commercial thermal, lighting and appliances. 
regions. The output thus represents national energy flows to the buildings sector, with technological detail presented in one region at a time. The model is run successively with each region represented in detail in turn to develop a full national projection.

The detailed regional flows go as follows. Each unit of the new variable representing the total gas to residential space heat can flow either to a gas heat pump or to a gas burner. If it flows to a burner, upon coming out of the burner it is multiplied by the energy-conversion efficiency. of the burner and incurs a cost equal. to the annualized capital cost of the burner if it is a new burner, or a zero cost if it is an old burner. If it flows through the heat pump it is multiplied by the seasonal performance factor of the heat pump, and incurs a cost equal to the annualized capital cost of the heat pump.

From the conversion device, energy may flow to any of 8 levels of thermal integrity for each building type. In Figure 2 , from the burner there are 32 possible paths ( 4 building types and 8 levels of thermal integrity).

Levels of thermal integrity are represented by 8 thermal shells for each building type. Shells 1 to 4 represent existing stock: shell 1 refers to an existing building without special conservation options and shells 2 to 4 refer to existing buildings with increasing levels of conservation features. similarly, for new buildings, shell 5 refers to a base building without any special conservation technology options (see 
Appendix B for building and conservation technology data).

A flow from the burner to a single family inherited shell with no additional insulation (shell 1) would be multiplied by the efficiency of the shell (1.0) and incur a cost of zero (since no energy-conserving capital stock has been purchased). A flow from the burner to an inherited shell retrofitted with energy-conservation features would have a higher efficiency and would incur a cost equal to the annualized capital cost of the conservation technologies implemented in that shell.

The flow from each shell enters the node representing total housing stock, where it is multiplied by the inverse of the theoretical load for that building type. This coefficient converts energy flow to actual numbers of housing units, or, conversely, it converts right-hand sides for the model, which are in physical units, (housing units in the residential sector and square feet in the commercial) to energy demands for each shell.

The air conditioning, thermal applications, and appliances for both the residential and commercial sectors are modeled in a similar way. Thermal applications include water heating, cooking and drying. The appliances category includes refrigeration, power loads (elevators, escalators, etc.) and miscellaneous electrical appliances.

\subsection{Economic Structure}

Flows of energy into the buildings network incur a cost equal to the price of the relevant energy form. The flow is allowed to take any of the paths corresponding. to a conversion 
device and shell combination as long as the total demand and other constraints described below are met.

When the energy flows through a node of the network (a conversion or shell technology), it is multiplied by the efficiency of that technology and charged the annualized capital charge for that technology. The optimization makes a lowestcost tradeoff to invest just the right amount in cnergy-conserving capital stock to improve efficiency to the point at which the lowest total cost of annualized capital plus the lowest total fuel cost is achieved.

Capital investments are charged an annual charge which is found by multiplying the initial investment by a capital recovery factor to calculate the annual payment required to retire the investment in a certain number of years.

$$
\text { Capital recovery factor }=\frac{i}{1-(1+i)^{-n}}
$$

where $i$ is the long-term discount rate and $\mathrm{n}$ is the equipment lifetime in years.

Different-equipment lifetimes and discount rates are used for residential and commercial markets and for new and retrofit technologies. These are input parameters in the model and can be easily varied.

The capital charges are applied to incremental investments from the 1975 base year building stock. That is, equipment existing in 1975 is not charged for capital cost, but post-1975 retrofits of existing buildings and investment in new construction are. This means that the optimized:capital stock derived in this way represents a preferred investment strategy for the 
period 1976 through the case year for which the model is programmed, on the assumption that decision makers act as though the case year prices are maintained from 1976 on.

\subsection{Structure of the Equations}

BESOM and BECOM are run simultaneously as a cost minimization problem. The BESOM equations will be described in detail elsewhere. 5 They may be classified as follows.

1. Supply equations limit the amount of a given resource that may be used in the planning year, either in total use or for a specific purpose. The constraints are given in terms of the energy content of the primary fuel (minemouth and wellhead) input to that supply category. For synthetic fuels and pumped storage, the supply constraint equations represent the energy content of the synthetic fuel after manufacturing.

2. Demand equations specify the energy requirements that must be met in order to satisfy demands from the demand sectors. They are specified as basic energy demands; each basic energy demand is defined as the amount of energy required to support an energy-utilizing activity assuming that the energy could be used at a reference technical efficiency (after conversion). Basic energy demands are specified for each of the demand categories.

3. Electrical supply and peaking constraint equations limit the electrical generating capacity of plant types as well as accounting for peak electric demands and energy balances. The peaking equations are of two types, weekly and seasonal, and describe off-peak power availability. 
4. Environmental constraints limit emissions of various types, such as $\mathrm{SO}_{\mathrm{x}}$ or particulates. However, in most model runs these constraints are not binding and serve only to sum up environmental effects.

5. Market penetration equations limit the technology penetration of markets, and relate to minimum or maximum levels of fuel use or permitted capacity of a particular type.

BECOM constraints may be grouped in the following classes.

1. Demand constraints. For each type of demand and building type, the flow from all shells to final demand must equal the theoretical building load times the building stock in the year for which consumption is projected.

$$
\sum_{j=1}^{8} \frac{1}{a_{k}} x_{j k}=b_{k} \quad \text { for all building types } k
$$

where

$$
\begin{aligned}
& a_{k}=\text { theoretical building load, } \\
& b_{k}=\text { total stock, and } \\
& x_{j k}=\text { flow from shell j to building } k .
\end{aligned}
$$

2. Minimum constraints on residual stock. The optimization is conducted for a given year. subject to the constraint that the number of dwelling units of a particular type heated by any given fuel.must equal the number that actually existed in the base year (1975) minus the removals in the period from the base to the yearfor which the analysis is performed.

$$
\sum_{j=1}^{4} \frac{l}{a_{k}} e_{j} d_{i} x_{i j}=b_{i k} \quad \begin{aligned}
& \text { for each conversion device } i \\
& \text { and shell } j, \text { for each building } \\
& \text { type } k
\end{aligned}
$$


where

$$
\begin{aligned}
c_{j}= & \text { efficiency of shell } j, \\
b_{i k}= & \text { total inherited stock (in physical units) of } \\
& \text { building type } k \text { with conversion device } i, \\
a_{k}= & \text { theoretical load for building type } k, \\
d_{i}= & \text { fuel adjustment factor for conversion device } i, \\
& \text { and } \\
x_{i j}= & \text { flow from conversion device } i \text { to shell } j .
\end{aligned}
$$

3. Seasonal load balance. In order to ensure that the heating, air-conditioning, thermal, and appliance loads for each shell are balanced, an equation exists for each shell setting this balance.

$$
x_{j k}-a_{k} \gamma_{j k}=0 \quad \text { for all shells } j \text { to building types } k
$$

where

$$
\begin{aligned}
x_{j k}= & \text { space-heating flow from shell } j \text { to total } \\
& \text { building type } k, \\
a_{k}= & \text { ratio of space-heating to air-conditioning } \\
& \text { load for building type } k \text {, and } \\
\gamma_{j k}= & \text { air-conditioning flow from shell } j \text { to build- } \\
& \text { ing type } k .
\end{aligned}
$$

4.. Fuel mix in new construction. The market shares of oil, gas, electric, and solar heated units are set in these equations reflecting current construction trends or the results of housing models.

$$
q_{i k} n_{k} \leq \sum_{i=1}^{r} \sum_{j=5}^{8} \frac{l_{k}}{a_{k}} d_{i} e_{j} x_{i j} \leq p_{i k} n_{k} \quad \underset{\text { types } k}{\text { for } k \text { building }}
$$


where

$$
\begin{aligned}
& a_{k}=\text { theoretical load of building type } k, \\
& d_{i}=\text { fuel adjustment factor, } \\
& e_{j}=\text { efficiency of shell } j, \\
& x_{i j}=\text { flow from conversion device } i \text { to shell } j, \\
& p_{i k}=\text { upper limit in percent market penetration } \\
& \quad \text { for fuel } i \text { in building type } k, \\
& q_{i k}=\text { lower limit in percent market penetration } \\
& \quad \text { for fuel } i \text { in building type } k, \\
& n_{k}=\text { new construction of building type } k, \text { and } \\
& r=\text { number of conversion devices using fuel } i .
\end{aligned}
$$

5. Seasonal operation constraints on heat pumps. Electric and gas heat pumps are constrained to have a ratio of heating and cooling equal to the ratio of heating/cooling loads for the relevant shell, building type, and region.

$$
\begin{aligned}
e_{j} x_{i j}-k_{j} \gamma_{i j}=0 \quad & \text { for all heat pumps, for all } \\
& \text { shells in each building type }
\end{aligned}
$$

where

$$
\begin{aligned}
& \begin{aligned}
x_{i j}= & \text { space-heating flow from heat pump } i \text { to shell } j, \\
\gamma_{i j}= & \text { air-conditioning flow from heat pump } i \text { to } \\
& \text { shell } j, \\
e_{j} & =\text { efficiency of shell } j \text { in the heating season, } \\
f_{j}= & \text { efficiency of shell } j \text { in the cooling season, } \\
& \text { and } \\
k & =\text { ratio of space-heating to cooling load. } \\
\text { Solar back up constraints. These equations require } &
\end{aligned} \\
& \text { that the use of solar energy be accompanied by a certain fraction }
\end{aligned}
$$


of back up from conventional energy sources to provide heating or cooling when insolation is insufficient. There is an equation for all new shells in each building type for solar space heating, air conditioning, and water heating. The fraction of back up varies depending on end use.

$$
\begin{gathered}
X_{b j}=f_{1} X_{s j} \quad \text { for all shells } j, \text { for all building } \\
\text { types, for each end use } 1
\end{gathered}
$$

where

$$
\begin{aligned}
& x_{b j}=\text { flow from backup device to shell } j, \\
& x_{s j}=\text { flow from solar unit to shell } j \text {, and } \\
& f_{1}=\text { fraction of load provided by backup device. }
\end{aligned}
$$

7. Solar AC constraints. These equations ensure that solar air conditioning can occur only in buildings that employ solar space hẹting, recognizing that solar air conditioning is never used by itself.

$$
x_{s j} \geq h x_{a j} \quad \text { for all shell } j \text {, for all building types : }
$$

where

$$
\begin{aligned}
& x_{s j}=\text { solar space heat to shell } j, \\
& x_{a j}=\text { solar air conditioning to shell } j, \text { and } \\
& h \quad=\text { ratio of heating to air-conditioning loads. }
\end{aligned}
$$

8. Solar water heating. These equations ensure that buildings employing solar space-heating systems derive their hot water from the same system.

$$
x_{t j} \geq x_{s j} \quad \text { for all shells } j \text {, for all building types }
$$

where

$$
\begin{aligned}
& x_{t j}=\text { solar water heating to sheli } j, \\
& x_{s j}=\text { solar space heating to shell } j, \text { and } \\
& k \quad=\text { ratio of water-heating load to space-heating load. }
\end{aligned}
$$




\section{Data Inputs}

Within the network flow conception we have outlined, internally consistent performance and cost data are used, taken from the Arthur D. Little data base for buildings ${ }^{6}$ summarized in Appendices $A$ and $B$. The main categories of data are the following.

1. Building stocks. These include inventory data for 1975 for four types of residences and five types of commercial buildings, removals in the period 1976-2000, new construction by type during 1976-2000, and total building stocks.

2. Theoretical building loads. These are defined as the energy required from any conversion device for the reference shell for various types of loads. They are different for different buildings types and different climatic conditions in various regions. They are specified for each region for reference structural technologies for the following categories: space heating, air conditioning, hot water, lighting plus power, and auxiliaries in commercial buildings.

3. Shell efficiencies. These are the percentage improvements in structural integrity, over a nominal 1975 value for new and existing buildings, which can be expected from implementation of certain technologies applicable to building envelopes.

4. Conversion-device efficiencies. These are the percentages of delivered energy which can actually be applied to the theoretical building loads. For heat pumps, for example, this corresponds to the seasonal performance factor.

5. Technology costs. These include the cost for conversion devices and structural technologies, both for new 
buildings and for retrofit applications.

Other efforts have been made at BNL and elsewhere ${ }^{7}$ to develop improved data for this model, and these will be continued. The ADI data base is being used currently because of its completeness and internal consistency and the extensive experience it embodies.

\section{Model Operation and Outputs}

The equations for the model are set up by using the Haverly Systems, Inc., general-purpose problem-description system (PDS/ MAGEN), which contains a bidirectional interface to the control Data Corporation APEX III linear programming system. The model is run on the APEX III. out-of-core system-1 under control of the SCOPE 2.1 operating system on Brookhaven's Control Data 7600 series computer.

Using PDS/MAGEN, a single control file generates the equations, with data inputs being stored in separate files (one for each region). Though each region uses the same control program, a run for any region is independent of the runs for the other regions.

For each case to be explored, the data inputs are total building stocks, bounds for building market shares by fuel, technology cost, and performance data, building loads for each end use (space heating, air conditioning, thermal, and appliances), and the relevant fuel prices. BESOM and BECOM are then run simultaneously as a cost-minimization problem. The combined problem has almost 3800 constraints and 6000 variables and takes almost $200 \mathrm{CPU}$ seconds to solve. 
Because of the complexity and size of the problem, a simplified format is used to present the output. This is written by using the report-generating. features of PDS/MAGEN. The information flow is shown schematically below.

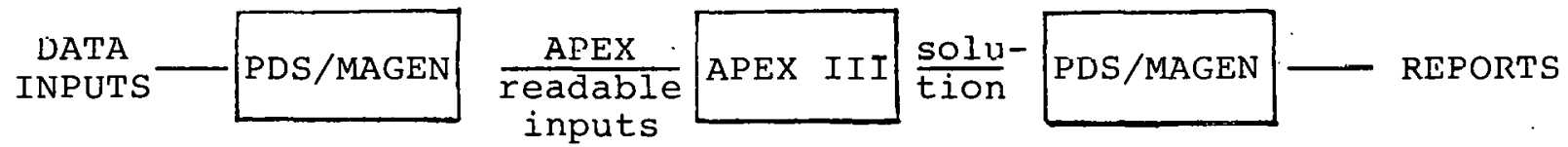

The output for each region is displayed at three different levels of aggregation. The first level, Figures 8 to 16, shows energy demand by building type. Conversion technologies with fuel are listed in the column at left. Structural technologies for both retrofitted and new buildings are listed across the top. Since each building option is in fact a combination of a conversion technology and a structural technology, each path represented by a given combination of fuel-firing device plus shell in the BECOM network is represented by a cell in this matrix. In the output, the fuel delivered ("over the fence") to each conversion device/shell technology combination is reported in the appropriate cell in the matrix. For each case year and policy scenario one of these matrices is prepared for each of nine building types. Retrofit $i$ ( or New i) is a category for a set of conservation technologies in buildings. The eight columns correspond to the eight shell definitions outlined earlier. The two-letter designation ( $\mathrm{SH}, \mathrm{AC}, \mathrm{TH}, \mathrm{AP}$ ) in the third column from the left identifies the end use that the conversion device is satisfying. All the numbers are in units of $10^{12} \mathrm{Btu}$.

The second level of aggregation sums the energy flows separately in residential buildings (Figure 17) and commercial buildings. 
(Figure 18). This enables one to find the energy demand by conversion device or end use for all buildings in a sector. The third level of aggregation presents net energy demand by fuel and end use for each region (Figure 19).

The regional totals in Figure 19 sum residential and commercial sectors for each region. The sum of these regional tables yields national demand totals by fuels in the two sectors.

Coverage of Output

Regions: Northeast, North Central, South, "West Building types: Residential-- Commercial-Single family Hospitals Low density Schools. Multi-family Retail Mobile homes Offices Miscellaneous

In addition, the results of each run are presented in terms of physical units which use each technology combination, expressed in $10^{9}$ square feet for commercial buildings and $10^{6}$ units for residential structures. A sample of this output is included in Figures 20 to 31 .

Finally, to facilitate calculation of investment requirements, the investment (in 1975 constant dollars) in energyrelated devices and structures during the period from 1976 through the case year is summarized. These data are presented by new and retrofit markets and building types for both devices and structures. These outputs are iliustrated in Figures 32 to 35. 


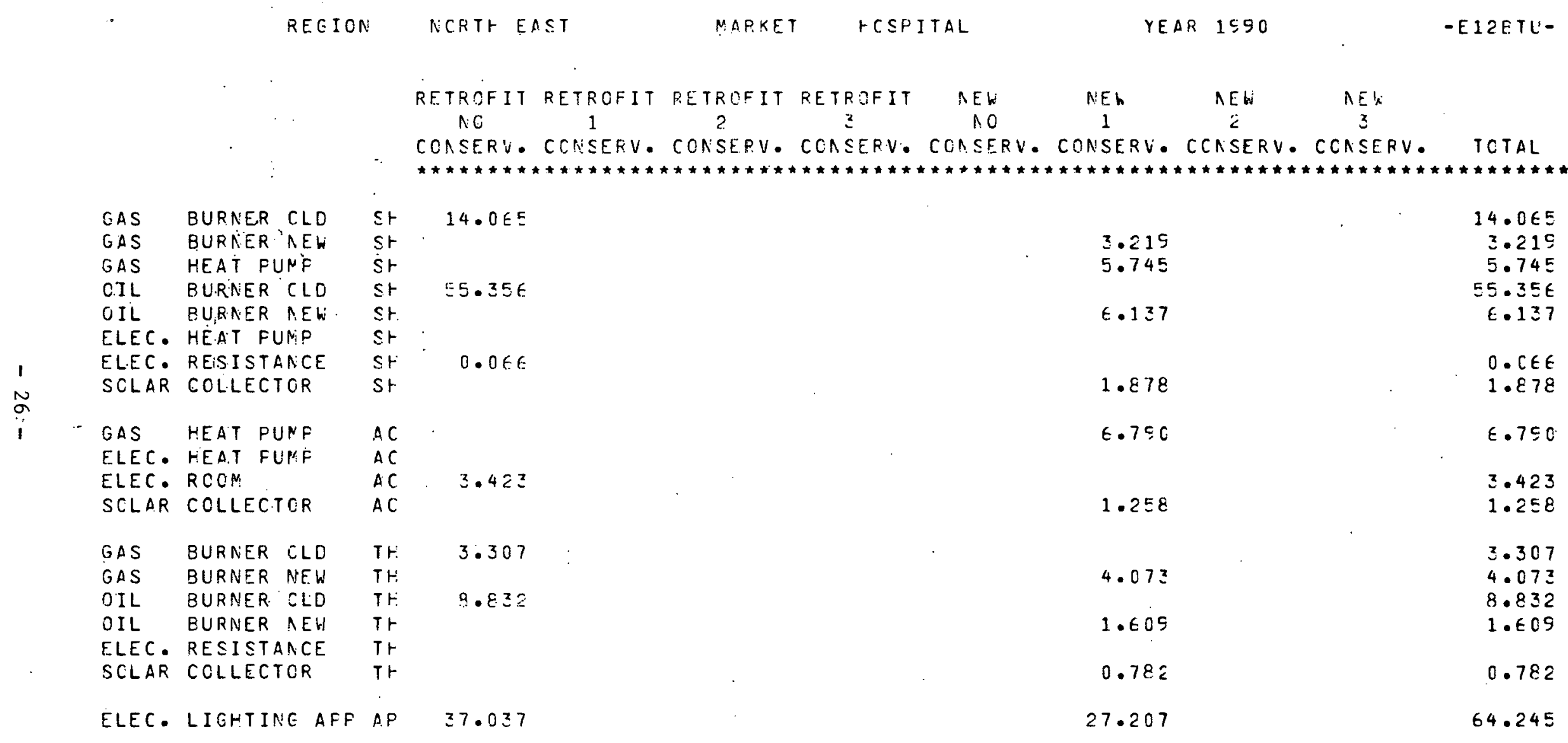

Figure 8. Buildings energy conservation optimization model. Case-base policy. 


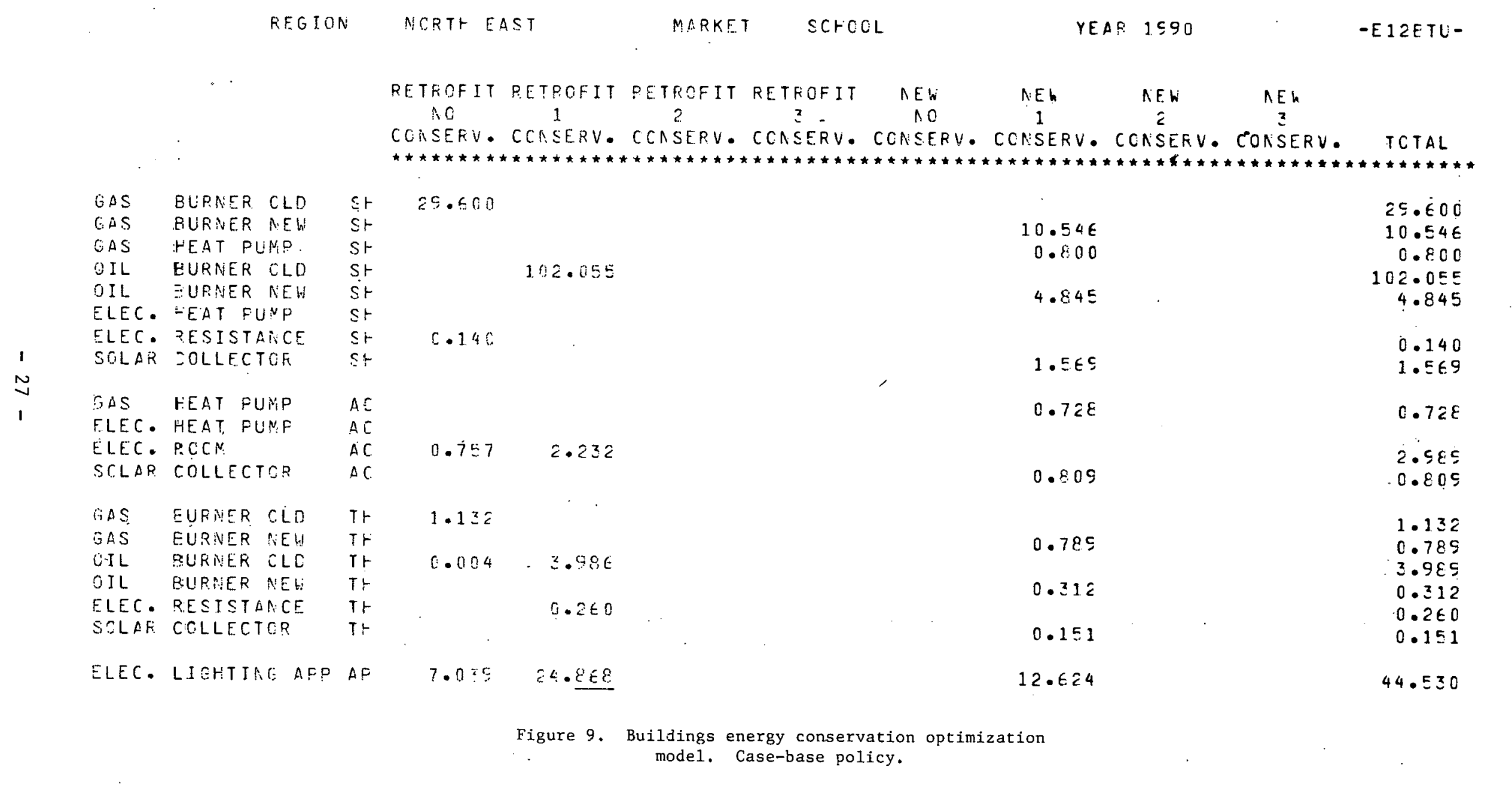


RETRCFIT PETFOFIT FETROFIT RETFOFIT AEW N NEW NEW

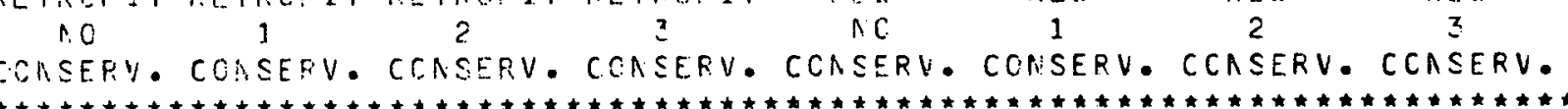

GAS EURNFR CLD SH

GAS BUPNEF NEH SH

GAS HEAT FUNP SH

OIL PUFNER CLE SH

OIL BURNER NEV SH

ELEC. HEAT FUNF SH

ELEC. RESISTARCE Sr

SCLAR COLLECTCR SH

GAS HEAT PUNF

ELEC. HEAT PUMP

ELEC. ROCM

SOLAR COLLECTOR

GAS BURNER CLD TH

GAS BURAER AEV TH

OIL BURAER CLO TH

GIL EURNER NEU TH

ELEC. RESISTMNCE TH

SCLAR COLLECTCR TH

ELEC. LIEHTINE AOP $\triangle P$

\subsection{8 .4}

$$
7 E \cdot E 15
$$

13.175

13.175

$$
3.673 \quad 5.230
$$

1.320

a. $\subseteq \in E$

z. 418

0.277

$17.057 \geq 2.563$

$\begin{array}{ll}13.437 & \\ 6.255 & \\ 6.002 & 4.016 \\ 6.155 & \\ 1.460 & 1.514 \\ 0.325 & 0.225 \\ 17.308 & 6.130\end{array}$

35.484

$1 \geq .437$

$E \cdot 295$

$75 . E 15$

10.018

13.175

2. 8.5

6.195

c. $50 x$

1. 514

1.320

1. $4 \in \mathrm{C}$

4.384

0.555

0.277

0.255

73.8 .58

Figure 10. Buildings energy conservation optimization model. Case-base policy. 
RETROFIT RETROFIT RETROFIT RETROFIT

$$
\text { AC }
$$

NEW NEW NEW D NEW

CONSERV - CONSERV - COASERV - CCNSERV - CONSERV - CONSERV - CCASERV - CCASERV.

GAS BURNER CLD SF

GAS BURNER NEW SH

GAS HEAT PUMP SH

OIL BURNER CLD SH

OIL BURAER NEW S

ELEC. HEAT PUNP S

ELEC. RESISTANCE S!

SCLAR COLLECTOR

GAS HEAT.PUNP

ELEC. HEAF -PUNF

ELEC. RGOM

SCLAR COLLECTCR

GAS BURNER OLL

G.AS BURNER NEW

OIL BURNER CLD

OIL BURNER NEW

ELEC. RESISTANCE

SOLAR COLLECTCR

ELEC. LIGHTING AFP AP
11.864

$47 \cdot 105$

$A C$

$A C$

$A C$

Tr

Tr
Tr
Tr

Tr

Tr

Tr

.

5.884

0.507

1.985

0.129

$70.1 \in 8$
0.058

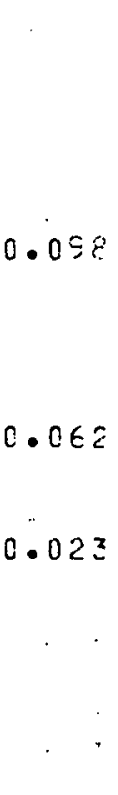

0.589
5.415

3.425

5.040

1.455

$7 . \geq \in 4$
11.804

5.415

3.425

47.105

5.040

0.058

1.455

$7.3 \in 4$

5.946

0.531

0.508

1. 985

0.355

0.129

0.174

116.658

Figure 11. Buildings energy conservation optimization model. Case-base policy. 


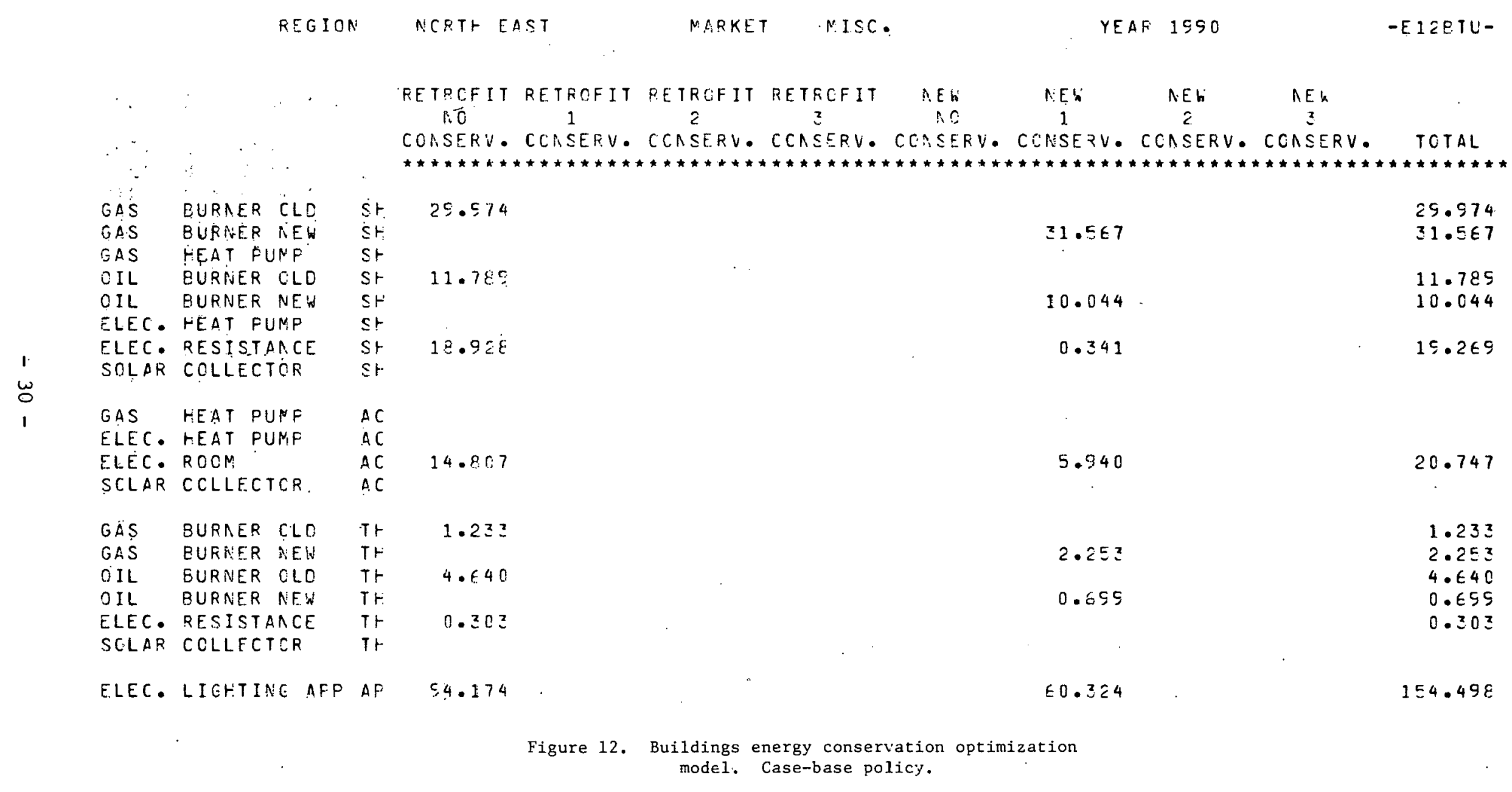




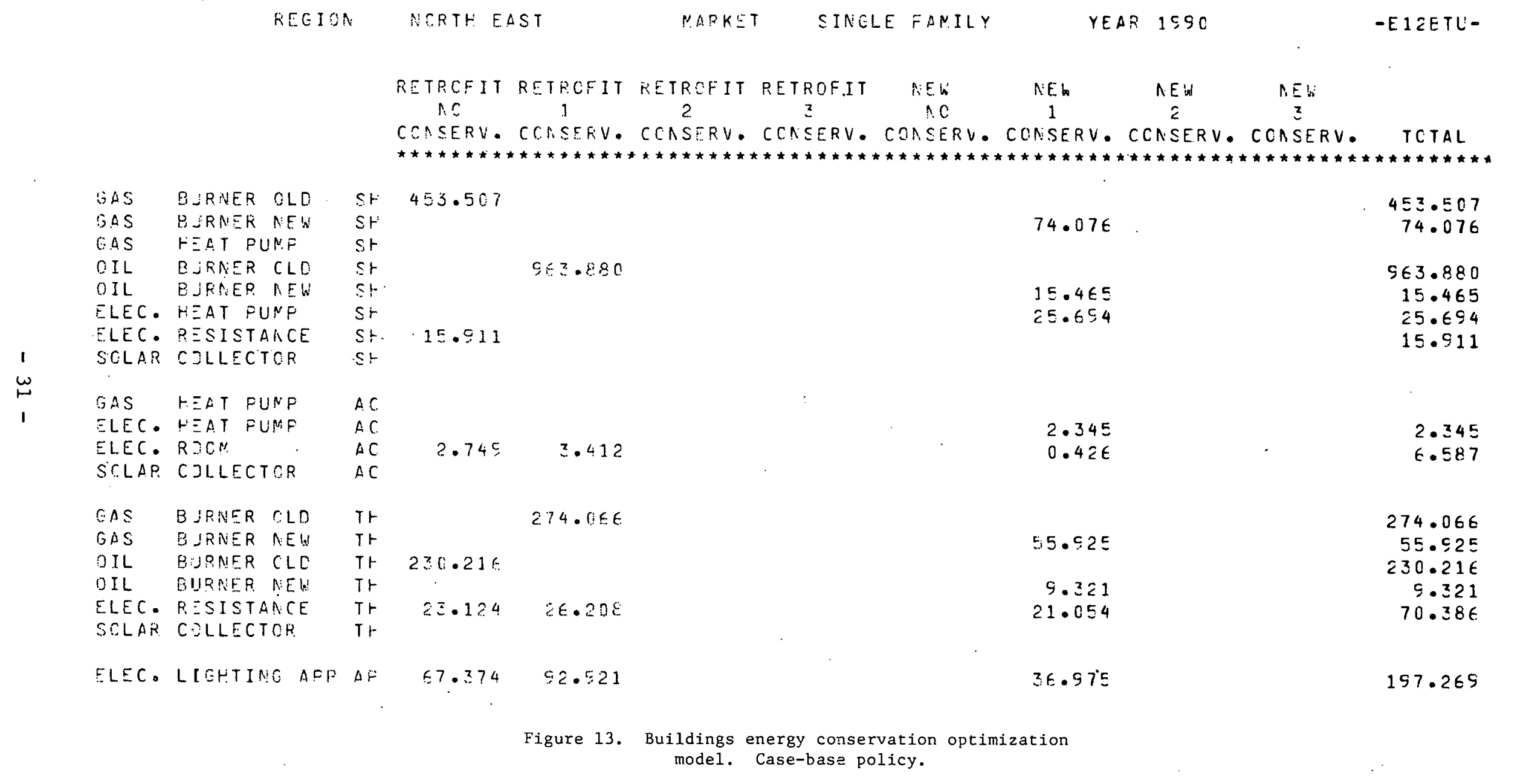


RETROFIT RETPCFIT RETEOFIT RETEOFIT
S. C 1 2 $z$

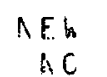
1
COASERV. COLSEFV. CONSERV. CCNSERV. COASERV. CONSERV - CCASERV. CONSERV.

: E h

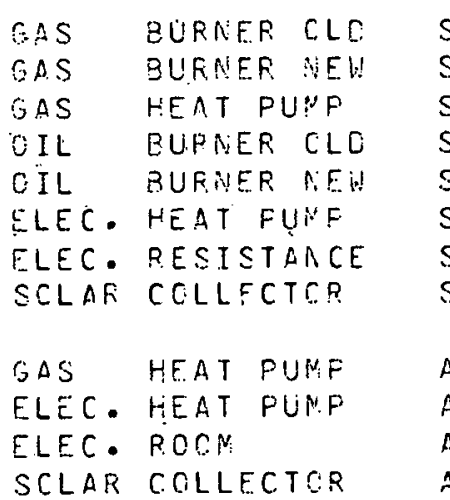
$s+$ $s t$ St $s-$ $s:$ St $S+$

$A C$

$A C$

$A C$

AC

GAS EURPER CLD TH

GAS EURIER AEH TH

OIL PURNER OLG TH

OIL PURHER MEW Tr

FLEC PESISTAACE TH

SCLAR COLLFCTCR. TH

ELEC. LIGHTINE AFF. AP

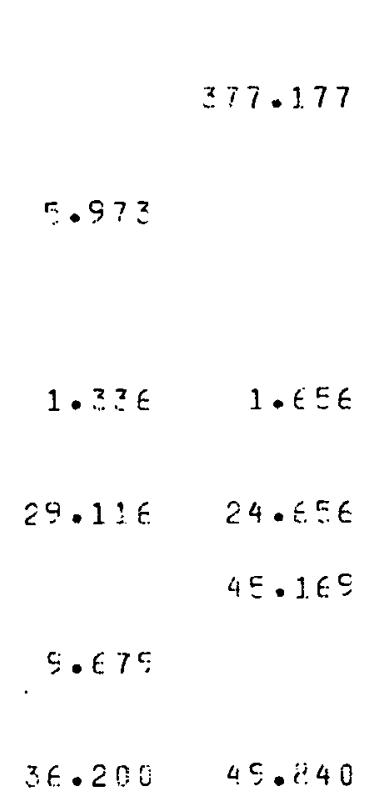

$22 \cdot 351$

181.919 $22 \cdot 3 \pm 1$

377.177

4. EEE

E. 901

5.973

\subsection{5}

$0.12 z$

$0 . \in 15$

3.173

6.353

1. 055

2.392

12.200
53.772

6.353

$45 \cdot 169$

1.059

12.071

98.340

Figure 14. Buildings energy conservation optimization model. Case-base policy. 


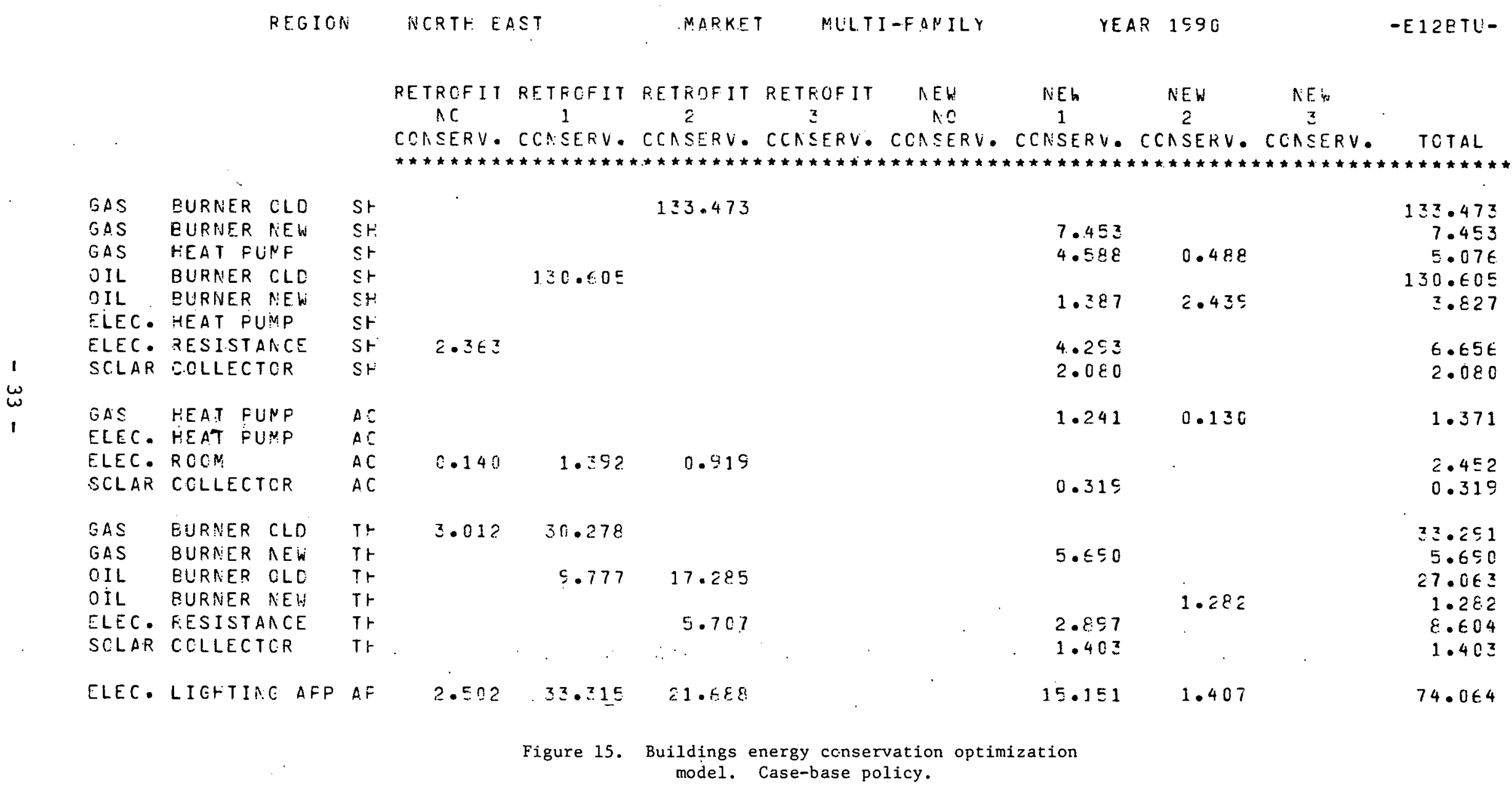


RETROFIT RETRCFIT RETROEIT RETRCFIT

$$
\text { AC }
$$$$
1
$$

$$
2 .
$$

$$
3
$$

N W

NO

NEW

CORSERV - CCHSEFV - COASERV - COASERV - CONSERV - CONSERV. COASERV. CCASERV.

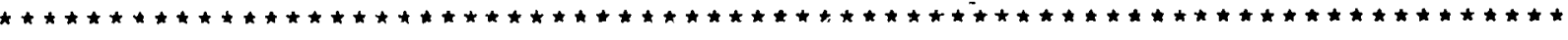

St

$\begin{array}{ll}6.360 \\ 0.312 \\ 0.005 & 0.156 \\ 0.217 & 2.001 \\ & 1.860 \\ & 0.355 \\ 0.221 & 4.371\end{array}$

AEW

NEG

ELEC. LIEHTING AFP AF
6.124

3.551

2.431

3. .51

$E . z \in 0$

E. 124

3.551

$15.55 \epsilon$

2.431

$4 \cdot 2 \in z$

1. $3 \in 0$

]. $z \in 0$

0.165

2.218

$3.40 E$

1. $8 \in 0$

0.80 .9

1.749

0.905

$7.3 \in 4$

$11.95 t$

Figure 16. Buildings energy conservation optimization model. Case-base policy. 


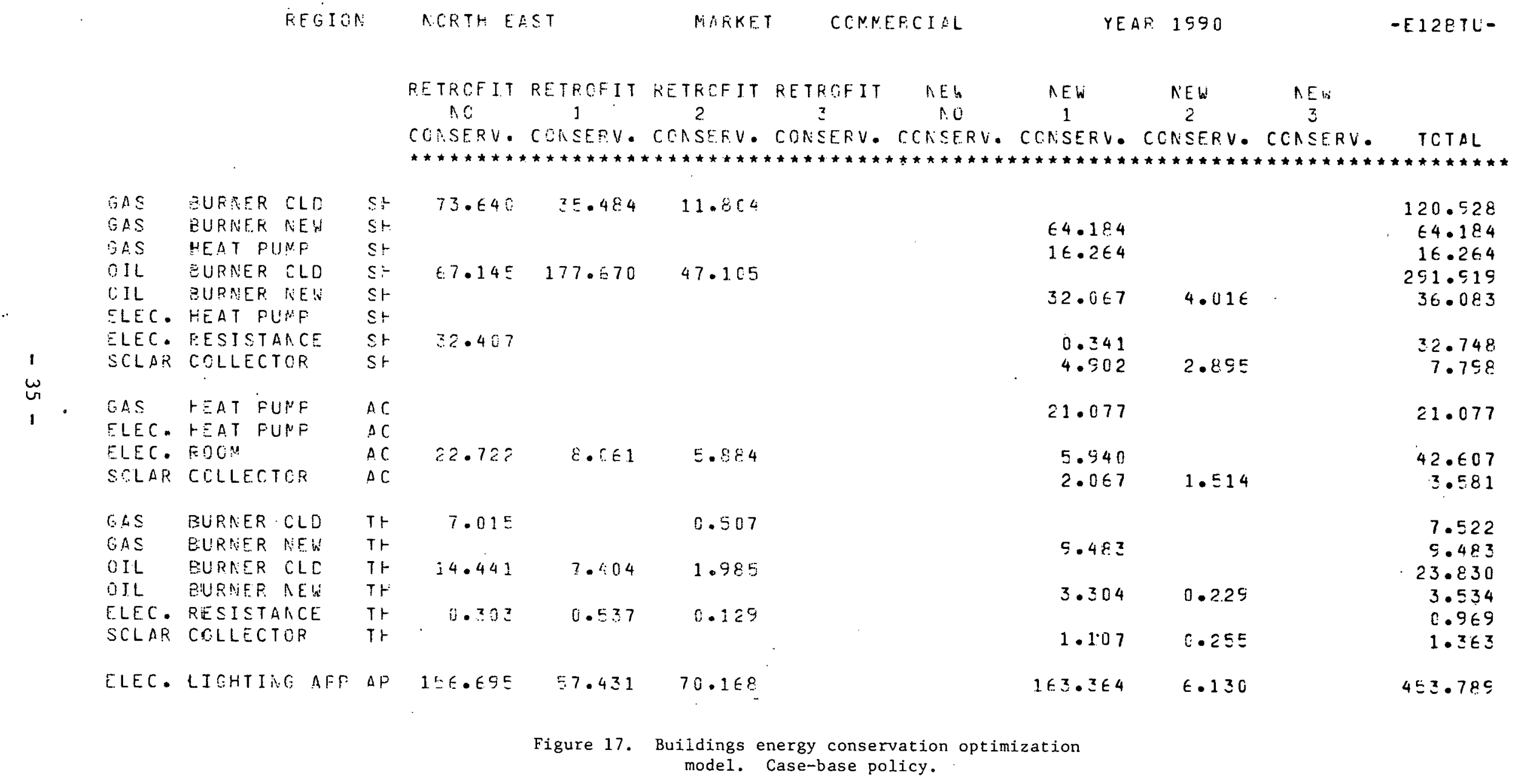




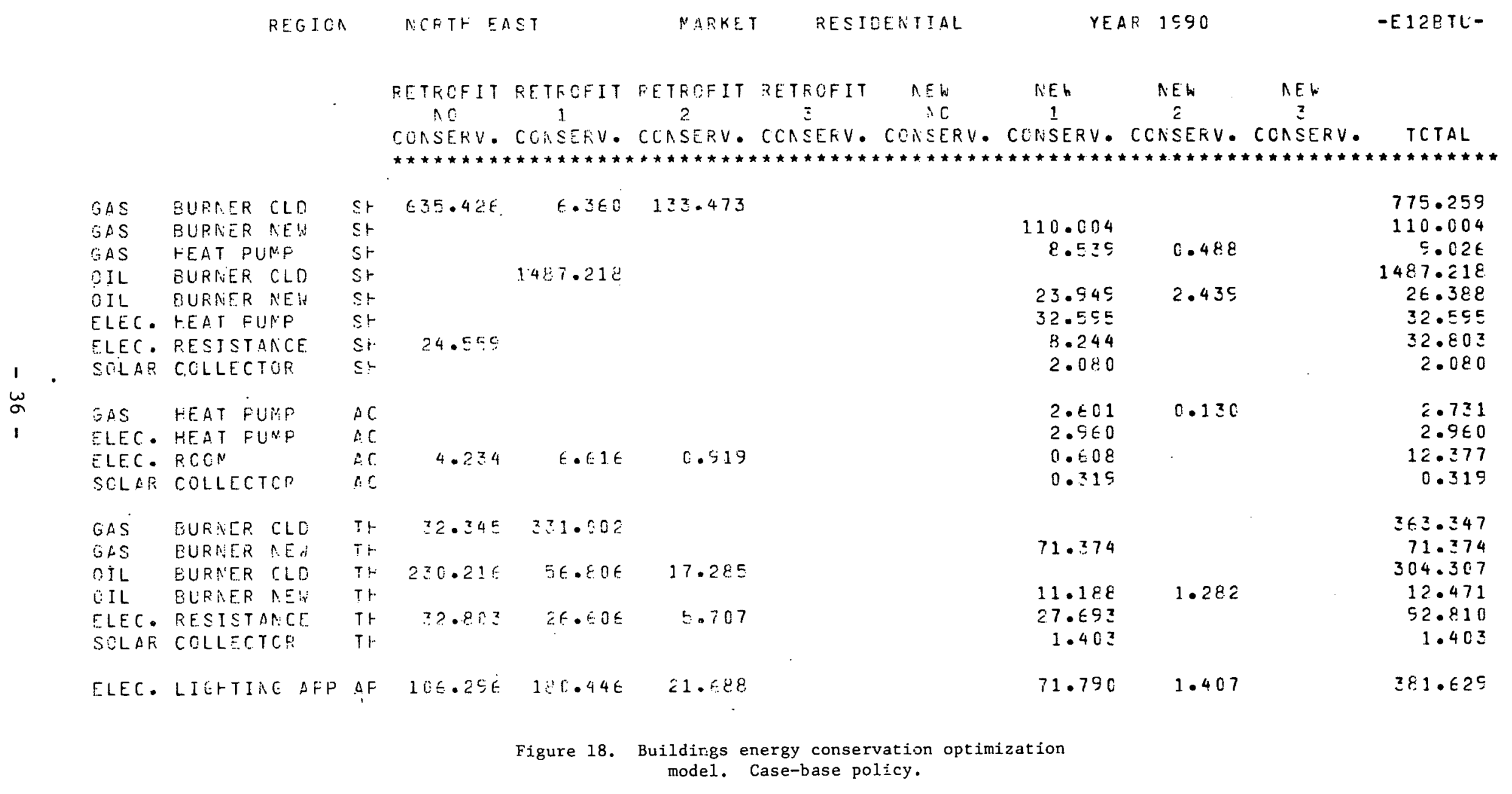




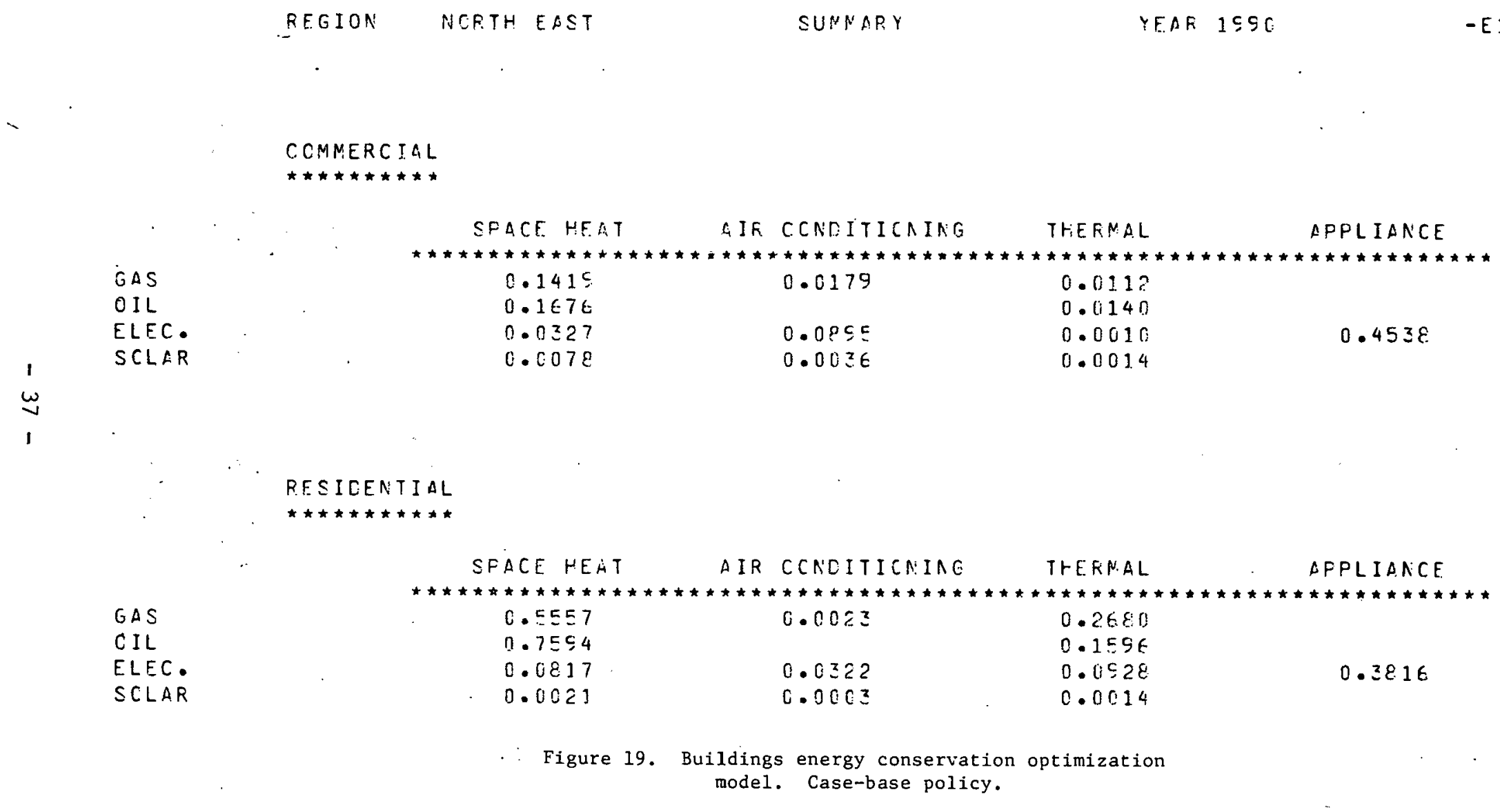




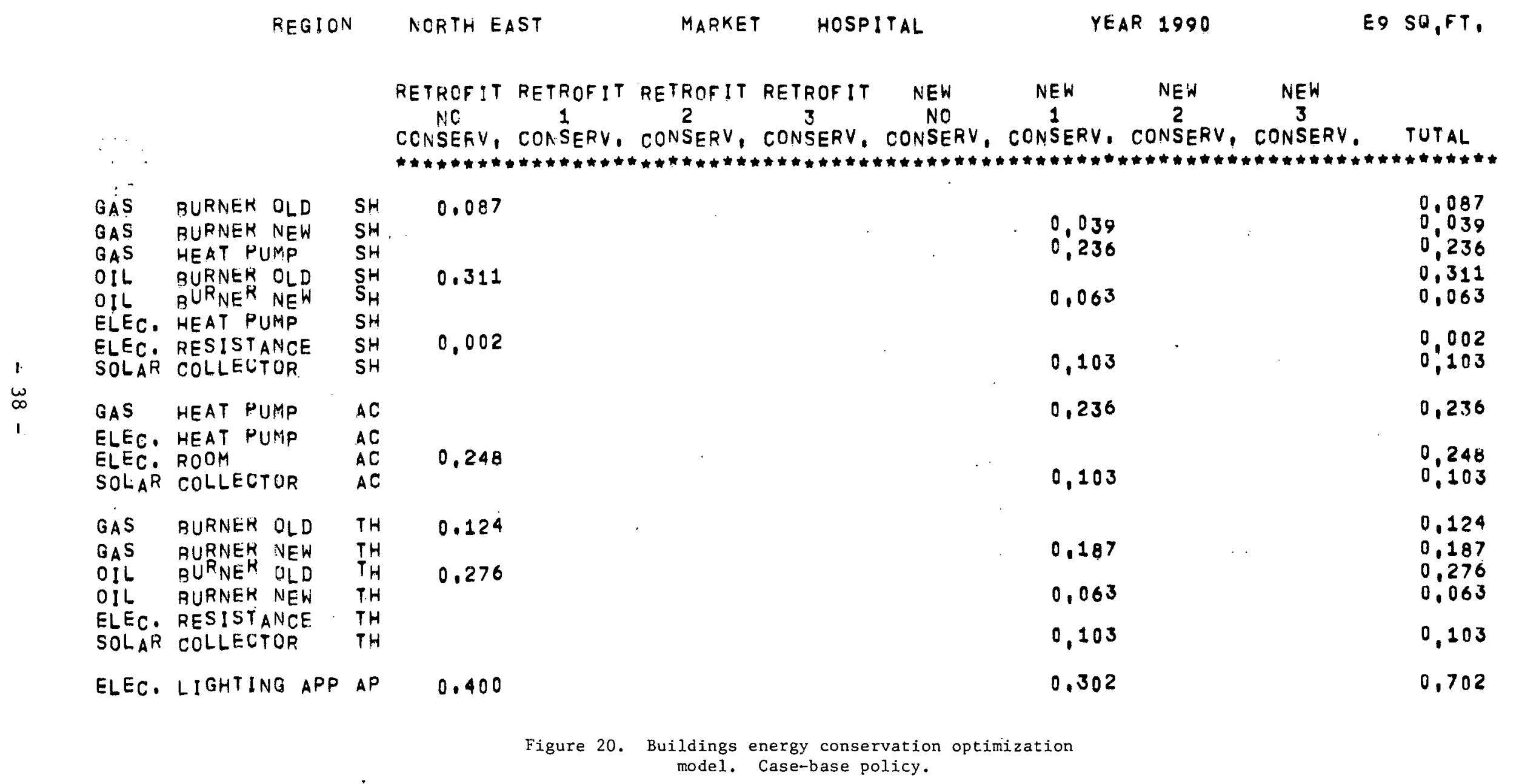


RETRCFIT RETROFIT RETROFIT RETROFIT NEW NEW NEW NEW

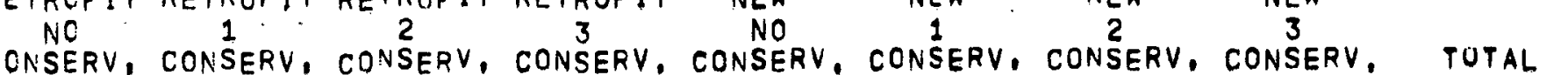

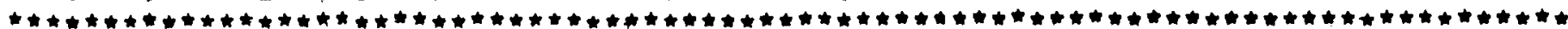

GAS

GAS

GAS

OIL

$0 I L$.

ELEC. HEAT PUNP

ELEC. FESISTANCE

SOLAR COLEECTOR

GAS REAT PUMP

ELEC. HEAT PUMP

ELEC. FOOM

SOLA ${ }^{R}$ COLLELTOR

GAS BURNER OID

GAS PURNEH NEW

OIL EURNEK OLD

OIL BURNER NEW

ELEC. RESISTANCE

SOLAR COLLECTOR

ELEC. LIGHTING APP AP

\subsection{2}

0.802

0.005

$$
0.057 \quad 0.201
$$

0.226

0.001

0.709

0.093

$0.227 \quad 0.802$

$$
\begin{aligned}
& 0.177 \\
& 0.043 \\
& 0.070 \\
& 0.113 \\
& 0.043 \\
& 0.113 \\
& 0.206 \\
& 0.070 \\
& 0.113 \\
& 0.332
\end{aligned}
$$

0,222

0,177

0.043

0,802

$0,0>0$

0,005

0,043

0,257

0,113

0,226

0.206

0,710

0,070

0,093

0,113

1,361

Figure 21. Buildings energy conservation optimization model. Case-base policy. 
REGION NORTH EAST MARKET OFFICE YEAR 1990 EQSW,FT,

RETROFIT RETROFIT RETROFIT RETROFIT NEW NEW NEW NEW CONSERV, CONSERV, CONSERV, CONSERV, CONSERV, CONS̈ERV, CONSERV, CONS̈ERV, TUTAL

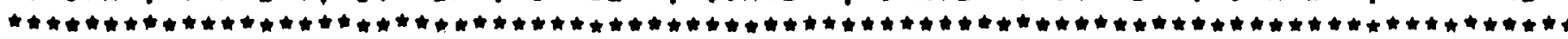

$\begin{array}{ll}\text { OAS } & \text { BURNEK OLD } \\ \text { GAS } & \text { RURNER NEW } \\ \text { OAS HEAT. PUMP } \\ \text { OIL BL BURER OLD } \\ \text { OIL. BURNER NEW } \\ \text { ELEC. HEAT PUMP } \\ \text { ELEC. RESISTANCE } \\ \text { SOLAR COLLECTOR } \\ \text { GAS, HEAT PUMP } \\ \text { ELEC. HEAT PUMP } \\ \text { ELEC ROOM } \\ \text { SOLAR COLLECTOR }\end{array}$

SH

SH

SH

SH

SH

SH

SH

SH

$A C$

$A C$

$A C$

$A C$

GAS BURNER OLD

GAS BURNER NEW

OIL BURNER OLD

OIL BURNER NEW

ELEC, RESISTANCE

SOLAR COLLECTOR

ELEC, LIGHTING APP AP

$\begin{array}{ll} & 0.263 \\ 0.425 & 0.512 \\ 0.234 & 0.426 \\ 0.264 & \\ 0.161 & 0.667 \\ 0.425 & 0.775\end{array}$$$
\begin{aligned}
& 0,186 \\
& 0,288
\end{aligned}
$$$$
0.071
$$$$
0,055
$$$$
0,204
$$$$
0.288
$$$$
0.204
$$$$
0.204
$$$$
0.372
$$$$
0,071
$$$$
0.055
$$$$
0,204
$$$$
0.443
$$$$
0,157
$$

$$
\begin{aligned}
& 0,263 \\
& 0,186 \\
& 0,288 \\
& 0,512 \\
& 0,126 \\
& 0,425 \\
& 0,204 \\
& 0,288 \\
& 0,660 \\
& 0,204 \\
& 0,264 \\
& 0,372 \\
& 0,828 \\
& 0,126 \\
& 0,108 \\
& 0,204 \\
& 1,800
\end{aligned}
$$

Figure 22. Buildings energy conservation optimization model. Case-base policy. 


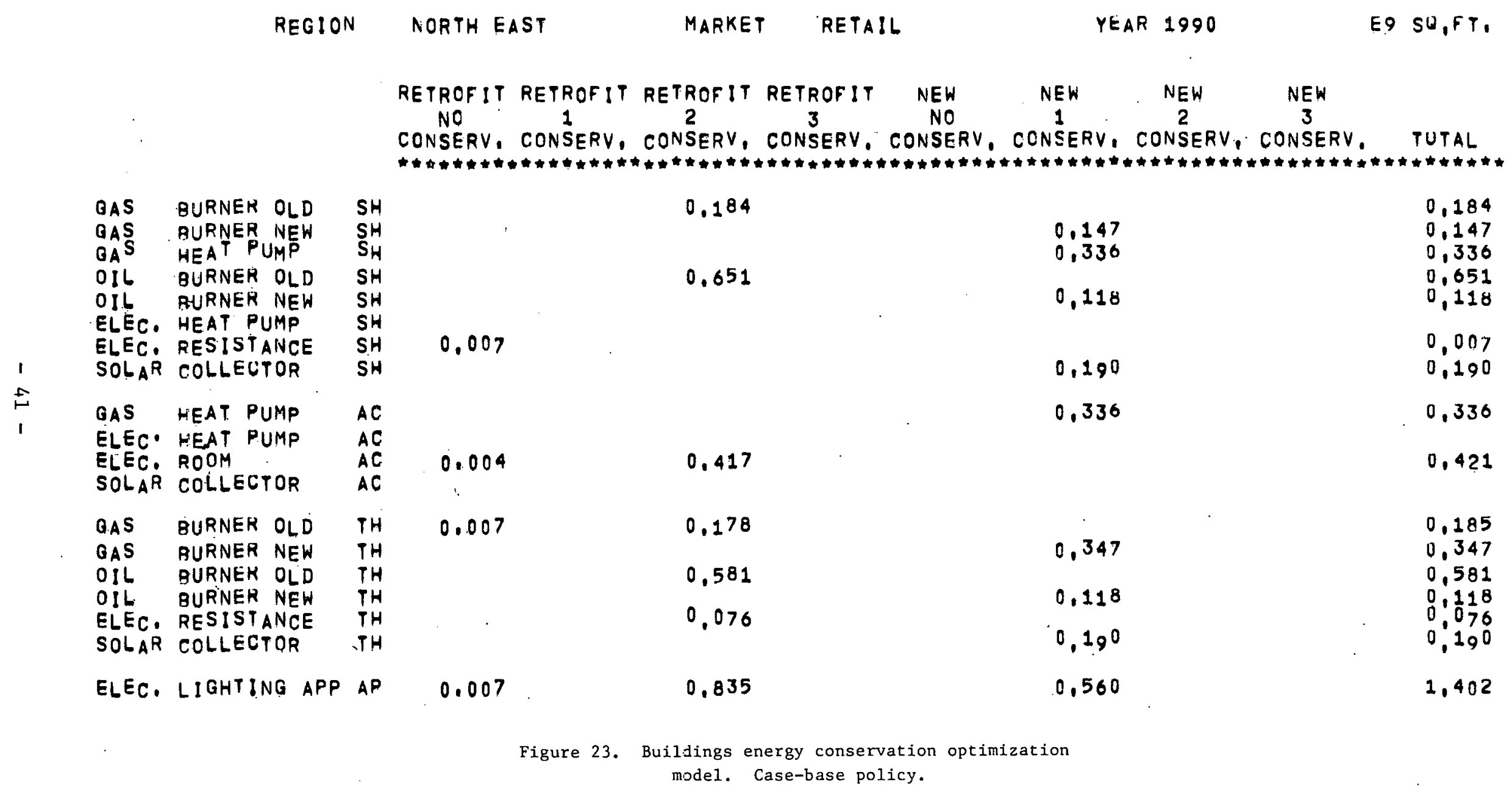


REGION

NORTH EAST

MARKET

MISC,

YEAR 1990

EQ SU,FT,
GAS BURNEK OLD SH

GAS RURNEK NEW SH

GAS HEAT PUMP SH

OIL BURNER OLD SH

OIL BURNEK NEW SH

ELEC. HEAT PUMP SH

ELEC. RESISTANCE SH

SOLAR COLLECTOR SH

GAS HEAT PUMP

ELEC, HEAT PUMP

ELEC. ROOM

SOLAR COLLECTOR

GAS BURNER OLD

GAS BURNER NEW

OIL AURNER OLD

OIL BURNER NEW

ELEC, RESISTAINCE

SOLAR COLLECTOR

ELEC, LIGHTING APP AP
RETROFIT RETROFIT RETROFIT RETROFIT

$$
\text { NO }
$$$$
2
$$

3

NEW

NEW

NEW

CONSERV, CONSERV, CONSERV, CONSERV, CONSERV, CONSERV, CONSERV, CONSERV, TOTAL

CONSERV, CONSERV, CONSERV, CONSERV, CONSERV, CONSERV, CONSERV, CONSERV, TOTAL
0.367
0.131
1.183
0.840
0.370
1.160
0.151
1.681

0,859

0.367

0,859
0,234

0,022

$0,67^{0}$

1,510

$0,88^{2}$

0,234

$0, \frac{131}{0.234}$

1,205

0,882

1.160

0,234

$1,116$.

2,797

Figure 24. Buildings energy conservation optimization model. Case-base policy. 


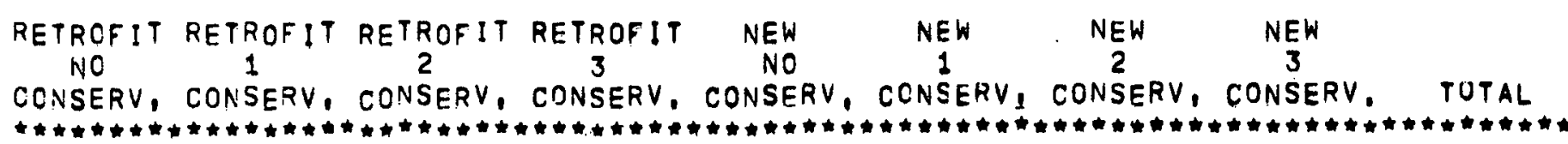

OIL BURNEK OLD SH

OIL RURNER NEW SH

ELEC. HEAT PUMP SH

ELEC, RESISTANCE SH

SOLAR COLLECTOR SH

GAS HEAT PUMP

ELEC. HEAT PUMP

ELEC. ROOM

2.895

LECTOR

GAS BURNEK DLD

GAS AURNER NEW

OIL BURNEK OLD

OIL RURINEH NEW

ELEC, PESIST ANCE

SOLAR COLLECTOR

ELEC, LIGHTING APP AP

$\begin{array}{ll}0.312 & 4.423 \\ 0.962 & 1.327 \\ 2.670 & 3.815 \\ 0.536 & 0.608 \\ 3.207 & 4.423\end{array}$

$$
\begin{aligned}
& 0.836 \\
& 0.150 \\
& 0.774 \\
& 0.774 \\
& 0.141 \\
& 1.047 \\
& 0.150 \\
& 0.563 \\
& 1.760
\end{aligned}
$$

2,895

0.836

4,423

0.150

0.774

0,312

0.774

2,430

3,815

1,047

2,670

0.150

1,708

9,390

Figure 25. Buildings energy conservation optimization model. Case-base policy. 
RETROFIT RETROFIT RETROFIT RETROFIT NEW NEW NEW NEW

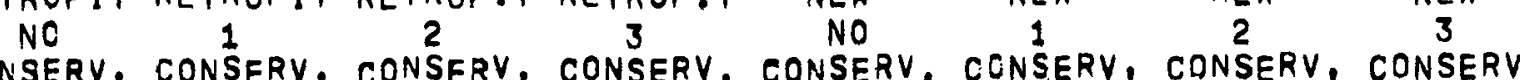

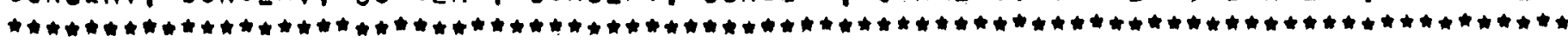

$\begin{array}{lll}\text { GAS } & \text { BURNER OLD } & \text { SH } \\ \text { GAS } & \text { BURNER NEW } & \text { SH } \\ \text { GAS } & \text { HEAT PUMP } & \text { SH } \\ \text { OIL } & \text { BURNER OLD } & \text { SH } \\ \text { OIL } & \text { BURNEH NEW } & \text { SH } \\ \text { ELEC. HEAT PUMP } & S H \\ \text { ELEC. RESISTANCE } & S H \\ \text { SOLAR COLLECTOR } & \text { SH } \\ \text { GAS } & \text { HEAT PUMP } & \text { AC } \\ \text { ELEC. HEAT PUMP } & \text { AC } \\ \text { ELEC. ROOM } & \text { AC }\end{array}$

1.629

$$
0.292
$$$$
1,629
$$$$
2,492
$$

$$
\begin{aligned}
& 0.052 \\
& 0.271
\end{aligned}
$$

SOLAR COLLECTOR

GAS BURNER OLD TH

GAS BURNER NEW

OIL BURNER OLD

OIL BURNER NEW

ELEC, RESISTANCE

SOLAR COLLECTOR

ELEC. LIGHTING APP AP

1,810

$1.165 \quad 0.986$

1,506

0.645

0,366

0,052

0,197

0,615
2,151

0.366

1,506

0,052

0,842

4,917

Figure 26. Buildings energy conservation optimization model. Case-base policy. 
RETROFIT RETROFIT RETROFIT RETROFIT $\begin{array}{ccc}\text { NO } & 1 & 1 \\ \text { CONSERV, CONSERV, CONSERV, CONSERV, CONSERV, CONSSERV, CONSERV, CONSERV, } & 2 & 3 \\ \end{array}$ CONSERV, CONSERV, CONSERV, CONSERV, CONSERV, CONSSERV, CONSERV, CONSERV, CONSERV, CONSERV, CONSERV, CONSERV, CONSERV, CONSERV, CONSERV, CONSERV.

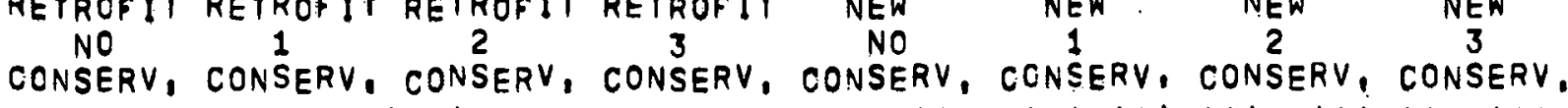

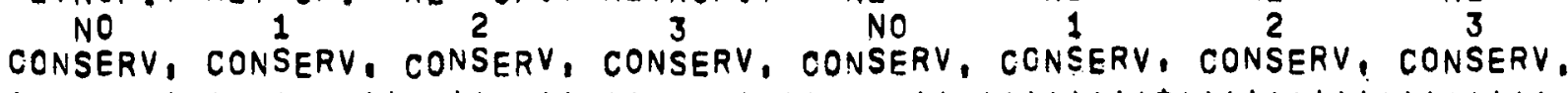

NEW

NEW

NEW

GAS BURNEH OLD SH

GAS BURNEH NEW SH

GAS HEAT PUMP SH

OIL BURNER OLD SH

OIL BURNEK NEW SH

ELEC. HEAT PUMP SH

ELEC. RESISTANCE SH

SOLAR COLLECTOR SH

GAS. HEAT PUMP

ELEC. HEAT PUMP

ELEC. ROOM.

SOLAR COLLECTOR

GAS BURNER OLD

GAS BURNER NEW

OIL BURNER OLD

OIL BURNER NEW

ELEC, RESISTANCE

SOLAR COLLECTOR

ELEC. LIGHTING APP AP
1,205

\section{$1 ; 851$}

0.139

$\begin{array}{lll}0.074 & 0.981 & 0.639\end{array}$

$0.139 \quad 1,459$

0.392

$$
0.726
$$$$
0.479
$$

$0.139 \quad 1.851 \quad 1.205$

$\begin{array}{ll}0.163 & \\ 0.472 & 0.057 \\ 0.026 & 0.052 \\ 0.294 & \\ 0.285 & \\ 0.472 & 0.057\end{array}$

1,205
0,163

0,529

1,851

0,078

0.433

0,285

0,529

1,693

0.285

0,285

1,598

0,405

1,118

0,078

0,774

0,285

0.285

0,842

0.078

4,115

Figure 27. Buildings energy conservation optimization nodel. Case-base policy. 
RETROFIT RETROFIT RETROFIT RETROFIT NEW
NO NEW
CONSERV, CONSERV, CONSERV, CONSERV, CONSERV, CONSERV, CONSERV, CONSERV, TUTAL

GAS BURNER OLD SH

GAS RURNER NEW SH

GAS HEAT PUMP SH

OIL RURNEK OLD SH

OIL RURNEA NEW SH

ELEC. HEAT PUMP SH

ELEC. RESISTANCE SH

SOLAR COLLECTOR SH

GAS HEAT PUMP

ELEC. HEAT PUMP

ELEC. ROOM

SOLAR COLLECTOR

GAS BURNER DLD TH

GAS BURNER NEW TH

OIL BURIVER OLD TH

OIL BURNEK NEW TH

ELEC, RESISTANCE TH

SOLAR COLLECTOR

ELEC. LIGHTING APP AP

$$
0.102
$$

$$
0.155
$$

0.013

0,208

0,037

0,139

0,208

$0.003 \quad 0.064$

$0.013 \quad 0.122$

0,094

0,040

0,245

0.050

$0.013 \quad 0.257$
0.102

0.108

0,208

0,155

0,037

0,152

0,208

0,068

0,135

0,245

0,094

0.050

0,179

0,703

Figure 28. Buildings energy conservation cptimization model. Case-base policy. 


\begin{tabular}{|c|c|c|c|c|c|c|c|c|c|c|}
\hline & REGIOI & & NORTH EA & AST & MARKET & COMME & ERC\AL & YEA & $R 1990$ & $=g \dot{S} U_{1} F T_{1}$ \\
\hline$\therefore$ & . & & $\begin{array}{c}\text { RETROFIT } \\
\text { NC } \\
\text { CONSERV } \\
\star \star * \star \star \star \star \star\end{array}$ & 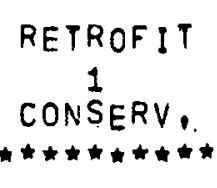 & $\begin{array}{l}\text { RETROFIT } \\
2 \\
\text { CONSERV, } \\
\star * \star_{*}\end{array}$ & $\begin{array}{l}\text { RETROF \T } \\
3 \\
\text { CONSERV } \\
\end{array}$ & 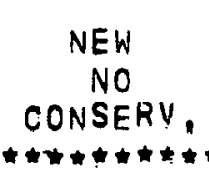 & $\begin{array}{c}\text { NEW } \\
1 \\
\text { CONSERV. }\end{array}$ & 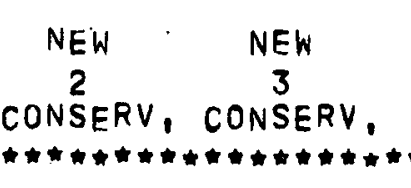 & TUTAL \\
\hline $\begin{array}{l}\text { GAS } \\
\text { GAS } \\
\text { GAS }\end{array}$ & $\begin{array}{l}\text { BURNEH OLD } \\
\text { BURNEK NEW } \\
\text { HEAT HUIAP }\end{array}$ & $\begin{array}{l}\text { SH } \\
\text { SH } \\
\text { SH }\end{array}$ & 0.676 & 0.263 & 0.184 & & & $\begin{array}{l}1,408 \\
0,903\end{array}$ & & $\begin{array}{l}1,123 \\
1,408 \\
0,903\end{array}$ \\
\hline $\begin{array}{l}\text { OIL } \\
\text { OIL } \\
\text { ELEC. }\end{array}$ & $\begin{array}{l}\text { BURNEK OLD } \\
\text { BURNEH NEW } \\
\text { HEAT PUMP }\end{array}$ & $\begin{array}{l}\text { SH } \\
\text { SH } \\
\text { SH }\end{array}$ & 0.442 & 1,314 & 0.651 & & & 0.556 & 0,055 & $\begin{array}{l}2,407 \\
0,611\end{array}$ \\
\hline $\begin{array}{l}\text { ELEC. } \\
\text { SOLAR }\end{array}$ & $\begin{array}{l}\text { RESISTANCE } \\
\text { CJLLECTOR }\end{array}$ & $\begin{array}{l}\mathrm{SH} \\
\mathrm{SH}\end{array}$ & 1.022 & & & & & $\begin{array}{l}0,022 \\
0,406\end{array}$ & 0,204 & $\begin{array}{l}1,644 \\
0.610\end{array}$ \\
\hline $\begin{array}{l}\text { GAS } \\
\text { ELEC. } \\
\text { ELEC } \\
\text { SOLA }\end{array}$ & $\begin{array}{l}\text { HEAT PUMP. } \\
\text { HEAT PUMP } \\
\text { RJOM } \\
\text { COLLECTOR }\end{array}$ & $\begin{array}{l}A C \\
A C \\
A C \\
A C\end{array}$ & 1,383 & 0.627 & 0,417 & & & $\begin{array}{l}0.903 \\
0.670 \\
0.216\end{array}$ & 0.204 & $\begin{array}{l}0,903 \\
3,090 \\
0,420\end{array}$ \\
\hline $\begin{array}{l}\text { GAS } \\
\text { GAS } \\
\text { OIL } \\
\text { OIL } \\
\text { ELEC. } \\
\text { SOLAR }\end{array}$ & $\begin{array}{l}\text { B JRNEK OLD } \\
\text { RURNEK NEW } \\
\text { BURNEK OLD } \\
\text { BURNER NEW } \\
\text { RESISTANCE } \\
\text { COLLECTOR }\end{array}$ & $\begin{array}{l}\text { TH } \\
\text { TH } \\
\text { TH } \\
\text { TH } \\
\text { TH } \\
\text { TH }\end{array}$ & $\begin{array}{l}0.991 \\
1.598 \\
0.151\end{array}$ & $\begin{array}{l}1.376 \\
0.201\end{array}$ & $\begin{array}{l}0.178 \\
0.581 \\
0.076\end{array}$ & & & $\begin{array}{l}1,994 \\
0,556 \\
0.406\end{array}$ & $\begin{array}{l}0,055 \\
0.204\end{array}$ & $\begin{array}{l}1,169 \\
1.994 \\
3,555 \\
0,611 \\
0,428 \\
0,610\end{array}$ \\
\hline ELEC. & L-GHTING APP & $A P$ & 2.740 & 1,577 & 0.835 & & & 2,753 & 0,157 & 8,062 \\
\hline
\end{tabular}

Figure 29. Buildings energy conservation optimization model. Case-base policy. 


REGION NORTHEAST, MARKET RESIDENTIAL YEAR 1990 EG UNITS

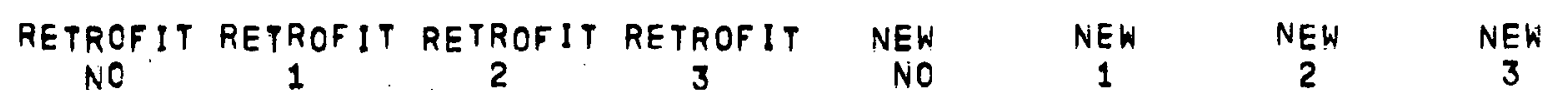

NO $\stackrel{1}{1}$, CONSERV, CONSERV, CONSERV, CONSERV, CONSERV, CONSERV, TOTAL

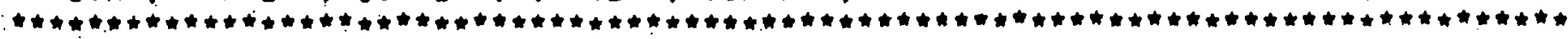

\begin{tabular}{|c|c|c|}
\hline 1 & $\begin{array}{l}\text { GAS } \\
\text { GAS } \\
\text { BAS } \\
\text { OIL } \\
\text { OIL } \\
\text { ELEC. } \\
\text { ELEC: } \\
\text { SOLAR }\end{array}$ & $\begin{array}{l}\text { BURNEH OLD } \\
\text { BURNEK NEW } \\
\text { HEAY PUMP } \\
\text { BURNEK OLD } \\
\text { BURNER NEW } \\
\text { HEAT PUMP } \\
\text { RESISTANCE } \\
\text { COLLECTOR }\end{array}$ \\
\hline 1 & $\begin{array}{l}\text { GAS } \\
\text { ELEC. } \\
\text { ELEC: } \\
\text { SOLAR }\end{array}$ & $\begin{array}{l}\text { HEAT PUMP } \\
\text { HEAT PUMP } \\
\text { ROOM } \\
\text { COLLECTOR }\end{array}$ \\
\hline & $\begin{array}{l}\text { GAS } \\
\text { OAS } \\
\text { OIL } \\
\text { OIL } \\
\text { ELEC. } \\
\text { SOLAR }\end{array}$ & $\begin{array}{l}\text { BURNER OLD } \\
\text { BURNER NEW } \\
\text { BURNER OLD } \\
\text { BURNER NEW } \\
\text { RESISTANCE } \\
\text { COLLECTOR }\end{array}$ \\
\hline
\end{tabular}

$\begin{array}{lll}4.524 & 0.102 & 1.205 \\ 0.645 & & \\ & 8,921 & \\ 1.600 & 3.145 & 0.839 \\ 1.317 & 0.382 & \\ 2.670 & 1.993 & 0.726 \\ 1.182 & 0.649 & 0.479 \\ 5.169 & 9.023 & 1.205\end{array}$

$A C \quad 1,600 \quad 3,145 \quad 0.639$

Figure 30. Buildings energy conservation optimization
1.400
0.680

0.057

$0.265 \quad 0.052$

1.045

0.433

0.680

1,045

0,221

0,285

0,057

5,831

1,400

0,737

8,921

0,317

1,045

1,078
0,285

0,737

1,045

5,604

0,285

7,699

2,063

5.389

0,330

0,530
0,585
0,285

0,252
0,285

3.650

0.078

19.125 model. Case-base policy. 


REGION NORTHEAST : SUMMARY YEAR 1990 PHY,UNITS

\section{COMMERCIAL}

SPACE HEAT AIR CONDITIONING THERMAL APPLIANCE

GAS

OIL $3,4340 \quad 0,9027 \% \$ \# \#+3,1634$

\begin{tabular}{|c|c|c|c|}
\hline $\begin{array}{l}3.4340 \\
3.0181 \\
1,6443 \\
0,6100\end{array}$ & $\begin{array}{l}0.9027 \\
3,0964 \\
0,4196\end{array}$ & $\begin{array}{l}3,1634 \\
4,1660 \\
0,4277 \\
0,6100\end{array}$ & 8,0620 \\
\hline
\end{tabular}

I SOLAR

0.6100

0,4196

0.4277

0,6100

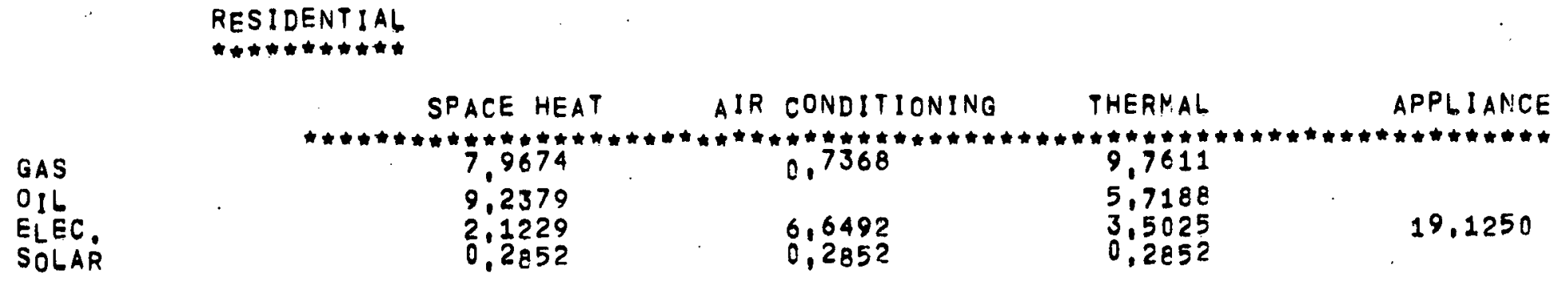

Figure 31. Buildings energy conservation optimization model. Case-base policy. 


\section{NEW}

\#\#

1.1483

LEVEL I

LEVEL I I

LEVEL III

LEVEL I

LEVEL I I

LEVEL I I I

1

ড

0.2968

\section{LOW DENSITY \\ MULTI-FAMILY}

MOBIL HOME

$\begin{array}{ll}\text { LEVEL I } & 0.1604 \\ \text { LEVEL I I } & 0.0276 \\ \text { LEVEL I I I } & \\ \text { LEVEL I } & 0.1714 \\ \text { LEVEL I I } & \\ \text { LEVEL I I I } & \end{array}$

1.8044
OLD

$\$ \$$

3.3965

1.1483

3.3965

1.4287

0.2968

1.4287

0.6864

0.1880

1. 3864

0.0643

0.1714

0.0643

Figure 32. Buildings energy conservation optimization

model. Capital investment in structural technologies (1975 s). 
NEW

OLD

\begin{tabular}{|c|c|c|c|c|c|c|}
\hline HOSPITALS & $\begin{array}{l}\text { LEVEL } \\
\text { LEVEL } \\
\text { LEVEL }\end{array}$ & $\begin{array}{l}\text { I } \\
\text { I I } \\
\text { I I I }\end{array}$ & 0.1046 & 0.1046 & . & \\
\hline SCHOOLS & $\begin{array}{l}\text { LEVFL } \\
\text { LEVEL } \\
\text { LEVFL }\end{array}$ & $\begin{array}{l}\text { I } \\
\text { I I } \\
\text { I I I }\end{array}$ & 0.1128 & 0.1128 & 0.5419 & 0.5419 \\
\hline OFF ICF 5 & $\begin{array}{l}\text { LEVFL } \\
\text { LEVEL } \\
\text { LEVEL }\end{array}$ & $\begin{array}{l}\text { I } \\
\text { I I } \\
\text { I I I }\end{array}$ & $\begin{array}{l}0.1054 \\
0.09 ? 0\end{array}$ & .0 .1973 & 0.3664 & 0.3664 \\
\hline RETAIL & $\begin{array}{l}\text { LEVEL } \\
\text { LEVEL } \\
\text { LEVEL }\end{array}$ & $\begin{array}{l}\text { I } \\
\text { I I } \\
\text { I I I. }\end{array}$ & 0.1308 & 0.1308 & 0.7108 & 0.7108 \\
\hline : & $\begin{array}{l}\text { LEVEL } \\
\text { LEVEL } \\
\text { LEVEL }\end{array}$ & $\begin{array}{l}\text { I } \\
\text { I I } \\
\text { I I I }\end{array}$ & 0.4503 & 0.4503 & . & \\
\hline TOTAL & & & 0.9959 & & 1.6191 & \\
\hline
\end{tabular}

Figure 33. Buildings energy conservation optimization

model. Capital investment in structural technologies (1975 \$). 


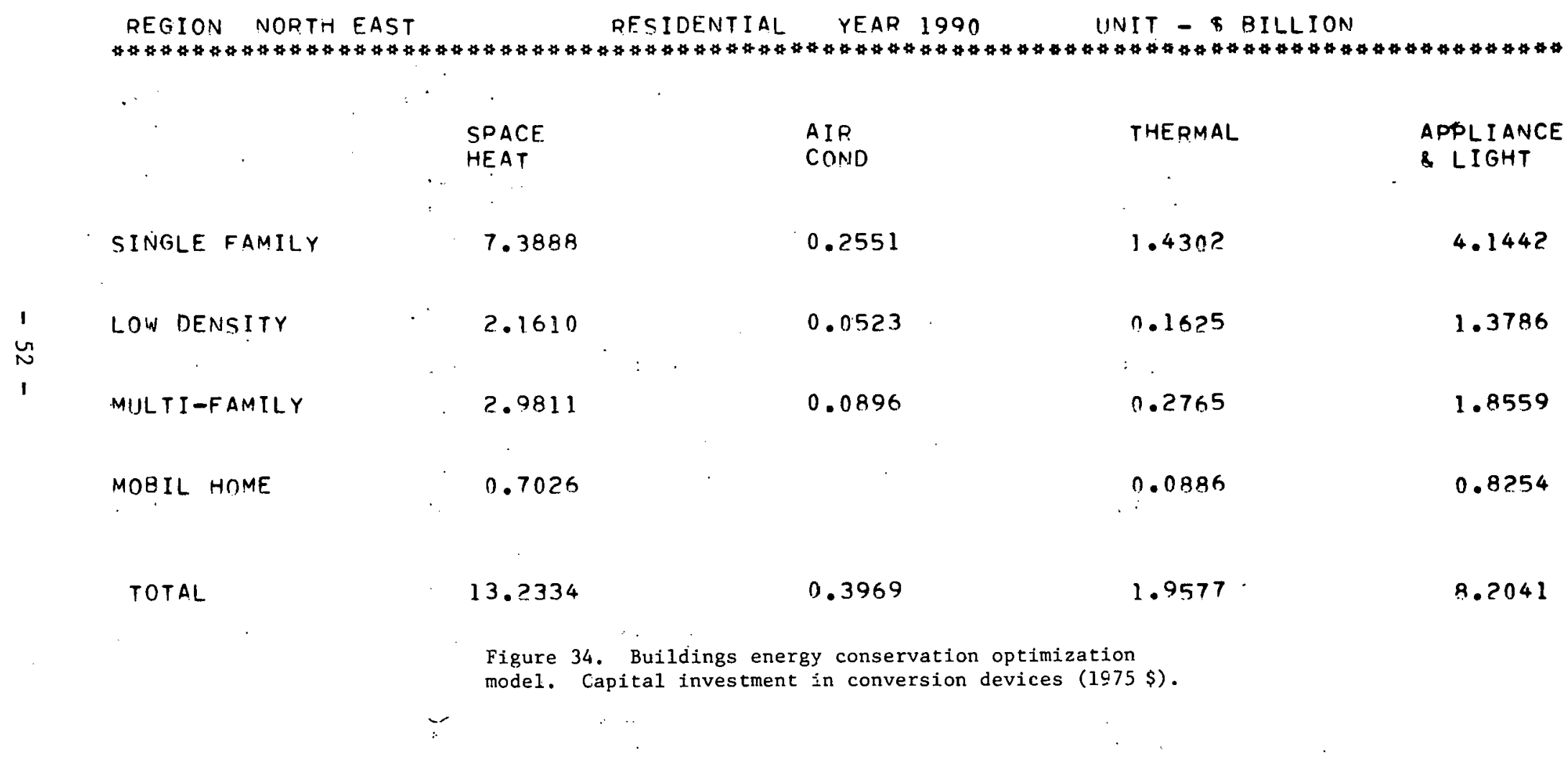


REGION NORTH EAST

COMMERCIAL

YEAR 1990

UNIT $-\$$ BILLION

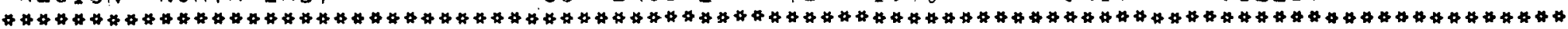

SPACE $\quad$ AIR

AIR

THERMAL

APPLI ANCE

HEAT

COND

\& LIGHT

HOSPITALS

3.4716

0.2132

0.1234

3.0762

SCHOOLS

1.5330

0.0932

0.0248

OFFICES

4.3642

0.2012

0.0451

2.6500

RETAIL

2.7071

0.0267

5.1899

MISC

0.4517

1.8152

0.0354

6.8207

TOTAL

12.6275

2.3227

0.2553

19.1641

Figure 35. Buildings energy conservation optimization

model. Capital investment in conversion devices (1975\$). 


\section{Applications}

The most important feature of the model from the point of view of the user is that BECOM consists of a multitude of individually specified building energy technologies which are selccted and assembled in a systematic way to project a picture of the entire stock of energy technologies in buildings and the resulting energy consumption. The technologies currently included comprise the major classes of conventional equipment and also major types of equipment under development. Novel and conventional equipment types compete on an equal basis.

These structural characteristics of BECOM make it especially suited for certain types of analysis.

1. Market penetration analysis. Because all types of equipment compete simultaneously, meaningful analyses of the relative roles of various technologies can be developed. Furthermore, since all possible combinations of conversion devices (such as HVAC equipment and.various structural improvements) are included, one can analyze the synergistic effects of combining various types of conversion devices and structural technologies. Unlike many other models of buildings energy demand, BECOM makes it is impossible to double-count energy savings.

Because it includes nine building types, two building classes (new and retrofit), and four regions, BECOM can be used to calculate the market penetrations of technologies in considerable detail and also on a national aggregate basis. Thus, the model identified both those technologies that have a 
large national impact and those that may be highly desirable in a limited market.

2. Policy analysis. A major question before the nation in relation to energy consumption in buildings is the role of various policy measures such as price regulation of various forms of energy, tax incentives for investment in specific building technologies, implementation of various code improvements, and setting of performance standards for appliances, air conditioning, and buildings. BECOM can analyze effects of such measures in a high degree of detail. Various pricing policies can be represented through input prices, which can be varied for different regions and consuming sectors. Tax incentives or other measures for changing the economics of building investment can and have been entered through adjustments to the capital charges for various building types. These adjustments can be different for each type of building just as they are likely to be for different classes of building owners. (Store owners will be treated differently than homeowners, for example.) Finally, regulatory action can be represented through constraints requiring or prohibiting certain technologies. in the various markets.

3. Analysis of research, development, and demonstration projects. Because BECOM makes projections of buildings energy demand by assembling an overall technological configuration. from many individual technologies, it is particularly. well sulted to examining the roie of these technologies in the context of total building energy consumption. 
Within BECOM, a technology is a generic type. For. example, the electric heat pump is one generic technology: DOE or other RD\&D projects related to electric heat-pump market share for each region or building type (if the project were so directed) indicated by BECOM. If the project were directed at achieving a particular cost or efficiency improvement, these parameters could be entered in the model to estimate the degree to which a given cost or improvement would improve market penetration, and the particular building types and regions where the increased market penetration would occur.

A. key feature of BECOM for RD\&D assessment is that the simultaneous competition of all technologies precludes double counting of energy savings' which could occur if energy savings from technologies were estimated without considering competing technologies. Also, since buildings are defined according to. both conversion devices and structural technologies, savings are attributed to the combined effect of conversion-device improvements and structural improvements, as will actually: occur in the field.

4. Sensitivity analysis. This type of analysis is closely related to the other areas outlined above. Because of the advanced programming system used for this model, one can quickly perform a series of evaluations of the types outlined, varying a single parameter (an energy price, for example, or the level of a tax credit) and produce a complete analysis of the entire buildings sector for each value of the parameter of 
interest. Thus the full effects of a specific decision variable. can be thoroughly analyzed.

5. Conservation implementation. BECOM is expected to be used in the near future to study the relationship between implementation of energy-conservation technologies (revealed, for example, through sales figures for insulation, heat pumps, and so forth) and yearly totals for energy consumption in buildings. By reconciling yearly sales totals of building energy technologies and total energy consumption within the BECOM framework, it will be possible to assess whether federal policies are having the anticipated effects on conservation-technology implementation and ultimately on energy consumption. If not, policy adjustments can be assessed.

6. Environmental effects of conservation in buildings. Reduced environmental impacts in the energy supply system as a whole are captured in BESOM. Detailed coefficients for emissions from the individual conversion devices included in BECOM are being developed. When this task is completed, detailed assessments of the environmental effects of buildings conservation policies can be performed. 


\section{Acknowledgements}

Many persons have made essential contributions to this program. William Marcuse orginally. conceived this approach to modeling energy conservation technologies, and he has provided continuing guidance and support. The overall building energy conservation program at BNL has been made possible by continuing interest and support from the Division of Buildings and Community Systems, particularly its director, Dr. Maxine Savitz, and Dr. S. Melvin Chiogioji and Joan Hock. Martin Glesk, leader of the Arthur D. Little case team on buildings, provided invaluable assistance in the form of data presented in the appendices to this report and also working suggestions. Comments from the Market Oriented Program Planning Study Residential and Commercial Working Group were helpful and essential, particularly those of Ed Blum and Eric Hirst.

Invaluable assistance was provided by Doreen Schneider and Marc Raisch of the BNL staff in assembling data and completing calculations. Barbara Nichols, Carmen Zopf, Marge Gallitelli, and Nancy Jesaitis provided their customary efficient and capable services in typing and assembly. Technical drawings were done by Stan Majeski. This effort has greatly benefited from the environment of Brookhaven's National Center for Analysis of Energy Systems, and especially from contact with several members who have worked in this general area - Kenneth Hoffman, Andy Kydes, Andres Doernberg, and Alan Hermelee. Responsibility for the paper remains, of course with the authors. 


\section{References}

1. Cherniavsky,E. A., Brookhaven Energy System Optimization Model, Informal Report, BNL 19569, 1974 .

2. Goldberg, M.D., An Energy Model Data Base, Informal Report, BNL 19200, undated (1973).

3. Beller, M., Editor, Sourcebook for Energy Assessment, BNL 50483, December 1975 .

4. Marcuse, W., Carhart, S., and Mulherkar, S., Residential energy demand analysis - Data and methodology, Presented at Joint National Meeting Operations Res. Soc. Am. and Institute of Management Science, Miami, November 1976 (BNL 21920).

5. Cherniavsky, E.A., Kydes, A.S., et al., Brookhaven Energy Systems Optimization Model - Methodology and Documentation (Version 2.1), BNL report, in preparation.

6. Glesk, M., et al., Report to Department of Energy on Building Technologies, Arthur D. Little, Inc., in preparation.

7. Daifuku, R., Residential space Heating and Cooling in New England 1972-2000, BNL 50614, December 1976 . 
THIS PAGE

\section{WAS INTENTIONALLY LEFT BLANK}


APPENDIX A

Residential and Commercial

Inventory and Forecasts 
RESIDENTIAL CONSTRUCTION INVENTORY FORECASTS

(thousand units)

1975

INVENTORY

$\underline{1976-1980}$

$\underline{1981-1985}$

$\underline{1986-2000}$

REMOVALS

1976-2000

2000

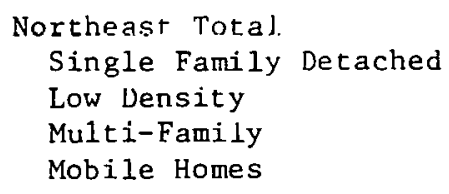

16,282

7,910

4,544

3,445

383

1,250

$$
1,500
$$

693

246

407

154
3,357
1,475
648
801
433

156

252

144
1,629
640
397
409
183
North Central Total
Single Family Detached
Low Density
Multi-Family
Mobile Homes

18,993

13,253

2,840

2,112

788
2,074
1,250
340
323

2,505

1,335

235

588

347
5,646
2,926
616
1,134
970

2,353

1,259

321

306

467

South Total

22,488

16,051

2,315

2,428

1,694

3,827

2,330

280

580

637

4, 647

2,477

10,504

5,499

1,106

1,045

683

1,988

1,911

3,439

2,014

255

236

934

5,926

13,067

8,379

1, 740

2,098

850

2,149

1,140

285

428

296

$$
2,628
$$

1,175

439

698

316

2,553

1,102

1,385

886

70,830

9,300

11,280

25,433

1,629

846

128

209

446

9,050

INVENTORY

20,760

10,136

5,197

4,496

931 .

26,865

17,505

3, 531

3, 868

1,961

38,027

24,343

3,888

5,805

3,991

22,141

12,401

3,438

4,400

1,902

U. S. Total

107,793 
COMMERCIAL CONSTRUCTION INVENTORY FORECASTS

(million square feet)

\begin{tabular}{|c|c|c|c|c|c|c|}
\hline & $\begin{array}{c}1975 \\
\text { INVENTORY } \\
\end{array}$ & $\begin{array}{c}\mathrm{NE} \\
1976-1980 \\
\end{array}$ & $\begin{array}{l}\text { CONSTRUCT: } \\
\underline{1981-1985} \\
\end{array}$ & $\begin{array}{l}1986-20 \rho 0 \\
\end{array}$ & $\begin{array}{l}\text { REMOVALS } \\
1976-2000 \\
\end{array}$ & $\begin{array}{c}2000 \\
\text { INVENTORY } \\
\end{array}$ \\
\hline $\begin{array}{l}\text { Northeast Total } \\
\text { Office \& Bank } \\
\text { Retail }\end{array}$ & $\begin{array}{r}5,688 \\
1,321 \\
928\end{array}$ & $\begin{array}{l}938 \\
193 \\
179\end{array}$ & $\begin{array}{l}980 \\
203 \\
190\end{array}$ & $\begin{array}{r}3,272 \\
660 \\
636\end{array}$ & $\begin{array}{l}879 \\
198 \\
139\end{array}$ & $\begin{array}{l}9,999 \\
2,179 \\
1,794\end{array}$ \\
\hline Schools & 1,150 & 114 & 107 & 342 & 199 & 1,514 \\
\hline Hospitals & 440 & 94 & 101 & 368 & 66 & 937 \\
\hline Other & 1,849 & 358 & 379 & 1,266 & 277 & 3,575 \\
\hline North Central Total & 6,674 & 1,169 & 1,217 & 4,089 & 1,135 & 12,014 \\
\hline $\begin{array}{l}\text { Office \& Bank } \\
\text { Retail }\end{array}$ & $\begin{array}{l}1,317 \\
1,517\end{array}$ & $\begin{array}{l}198 \\
334\end{array}$ & $\begin{array}{l}207 \\
354\end{array}$ & $\begin{array}{r}675 \\
1,195\end{array}$ & $\begin{array}{l}224 \\
258\end{array}$ & $\begin{array}{l}2,173 \\
3,142\end{array}$ \\
\hline Schools & 1,812 & 190 & 179 & 576 & 308 & 2,449 \\
\hline Hospitals & 511 & 113 & 122 & 448 & 87 & 1,107 \\
\hline Other & 1,517 & 334 &, 355 & 1,195 & 258 & 3,143 \\
\hline South Total & 7,320 & 1,273 & 1,379 & 4,783 & 1,464 & 13,291 \\
\hline Office \& Bank & 1,650 & 265 & 288 & 975 & 330 & 2,848 \\
\hline Retail & 1,589 & 317 & 349 & 1,212 & 318 & 3,149 \\
\hline Schools & 1,530 & 167 & 162 & 540 & 306 & 2,093 \\
\hline Hospitals & 486 & 113 & 127 & 480 & 97 & 1,109 \\
\hline Other & 2,065 & 411 & 453 & 1,576 & 413 & 4,092 \\
\hline West Tutal & $.4,781$ & 811 & 891 & 3,106 & 813 & 8,776 \\
\hline Office \& Bank & 1,146 & 185 & 203 & 690 & 195 & 2,029 \\
\hline Retail & 960 & 180 & 202 & 706 & 163 & 1,884 \\
\hline Schools & 934 & 104 & 102 & 342 & $159^{\circ}$ & 1,323 \\
\hline Hospitals & 294 & 70 & 80 & 304 & 50 & 698 \\
\hline Other & 1,447 & 272 & 304 & 1,064 & 246 & 2,842 \\
\hline U.S. Total & 24,463 & 4,191 & 4,467 & 15,250 & 4,291 & 44,080 \\
\hline
\end{tabular}


Building Units and \% Air Conditioned - 1976-2000

New - Non Residential 1976-2000

\begin{tabular}{|c|c|c|c|c|c|}
\hline & & $\underline{N E m}$ & & RETRC & \\
\hline & & $\begin{array}{c}\text { Built } \\
1976-2000 \\
\end{array}$ & $\% A C$ & $1976-2000$ & $\% \mathrm{AC}$ \\
\hline Northeast & $\begin{array}{l}\text { Offices } \\
\text { Ret. \& Other } \\
\text { Schools } \\
\text { Hospitals }\end{array}$ & $\begin{array}{r}1,056 \\
3,008 \\
563 \\
563\end{array}$ & $\begin{array}{l}65 \\
60 \\
30 \\
95\end{array}$ & $\begin{array}{r}1,123 \\
2,361 \\
978 \\
374\end{array}$ & $\begin{array}{l}55 \\
50 \\
25 \\
62\end{array}$ \\
\hline North Ceztral & $\begin{array}{l}\text { Offices } \\
\text { Ret. \& Other } \\
\text { Schools } \\
\text { Hospitals }\end{array}$ & $\begin{array}{r}1,080 \\
3,767 \\
945 \\
683\end{array}$ & $\begin{array}{l}65 \\
60 \\
50 \\
97\end{array}$ & $\begin{array}{r}1,093 \\
2,518 \\
1,504 \\
424\end{array}$ & $\begin{array}{l}50 \\
45 \\
32 \\
56\end{array}$ \\
\hline Soutii & $\begin{array}{l}\text { Offices } \\
\text { Rét. \& Other } \\
\text { Schools } \\
\text { Hospitals }\end{array}$ & $\begin{array}{r}1,528 \\
4,318 \\
869 \\
720\end{array}$ & $\begin{array}{r}95 \\
90 \\
75 \\
100\end{array}$ & $\begin{array}{r}1 ., 320 \\
2,923 \\
1,224 \\
385\end{array}$ & $\begin{array}{l}70 \\
65 \\
60 \\
75\end{array}$ \\
\hline West & $\begin{array}{l}\text { Office } \\
\text { Ret. \& Other } \\
\text { Schools } \\
\text { Hospitals }\end{array}$ & $\begin{array}{r}1,078 \\
2,725 \\
545 \\
454\end{array}$ & $\begin{array}{r}83 \\
80 \\
70 \\
100\end{array}$ & $\begin{array}{r}951 \\
1,998 \\
775 \\
244\end{array}$ & $\begin{array}{l}60 \\
55 \\
52 \\
67\end{array}$ \\
\hline
\end{tabular}


Building Units and \% Air Conditioned - 1976-2000 New and Retrofit

\begin{tabular}{|c|c|c|c|c|c|}
\hline & & $\begin{array}{l}\text { New Units } \\
1976-2000\end{array}$ & $\stackrel{\therefore}{\because} \therefore C^{*}$ & $\begin{array}{l}\text { Retro } \\
\text { Units }\end{array}$ & $\approx A C^{*}$ \\
\hline Nortieast & $\begin{array}{l}\text { Single Family } \\
\text { Low Density } \\
\text { Multi-Family } \\
\text { Mobile Homé }\end{array}$ & $\begin{array}{l}2.85 \% \\
1,050 \\
1.45 ! \\
73 !\end{array}$ & $\begin{array}{l}52 \\
57 \\
73 \\
48\end{array}$ & $\begin{array}{r}7,270 \\
4,147 \\
3,036 \\
200\end{array}$ & $\begin{array}{l}30 \\
31 \\
53 \\
25\end{array}$ \\
\hline Norti: Sectral & $\begin{array}{l}\text { Single Family } \\
\text { Low Density } \\
\text { Multi-Family } \\
\text { Mobile Home }\end{array}$ & $\begin{array}{l}5,511 \\
1,012 \\
2,06 ? \\
1,540\end{array}$ & $\begin{array}{l}70 \\
73 \\
87 \\
45\end{array}$ & $\begin{array}{r}11,994 \\
2,519 \\
1,805 \\
321\end{array}$ & $\begin{array}{l}43 \\
34 \\
67 \\
30\end{array}$ \\
\hline South & $\begin{array}{l}\text { Single Family } \\
\text { Low Density } \\
\text { Multi-Family } \\
\text { Mobile Home }\end{array}$ & $\begin{array}{r}10,305 \\
1,820 \\
3,013 \\
3,231\end{array}$ & $\begin{array}{l}87 \\
90 \\
95 \\
85\end{array}$ & $\begin{array}{r}14,037 \\
2,060 \\
2,192 \\
760\end{array}$ & $\begin{array}{l}48 \\
43 \\
77 \\
35\end{array}$ \\
\hline West & $\begin{array}{l}\text { Single Family } \\
\text { Low Density } \\
\text { Multi-Family } \\
\text { Mobile Home }\end{array}$ & $\begin{array}{l}4,868 \\
1,826 \\
2,5 i 1 \\
1,498\end{array}$ & $\begin{array}{l}70 \\
75 \\
82 \\
72\end{array}$ & $\begin{array}{r}7,533 \\
1,612 \\
1,889 \\
404\end{array}$ & $\begin{array}{l}35 \\
31 \\
39 \\
35\end{array}$ \\
\hline
\end{tabular}


THIS PAGE

\section{WAS INTENTIONALLY LEFT BLANK}




\section{APPENDIX B}

- Theoretical Loads for Buildings

- Conservation Technology Costs and Savings

- First Costs of Conventional HVAC Equipment 
THEORETICAL BUILDING ENERGY LOADS

\section{RESIDENTIAL - NEW CONSTRUCTIION 1976-1980}

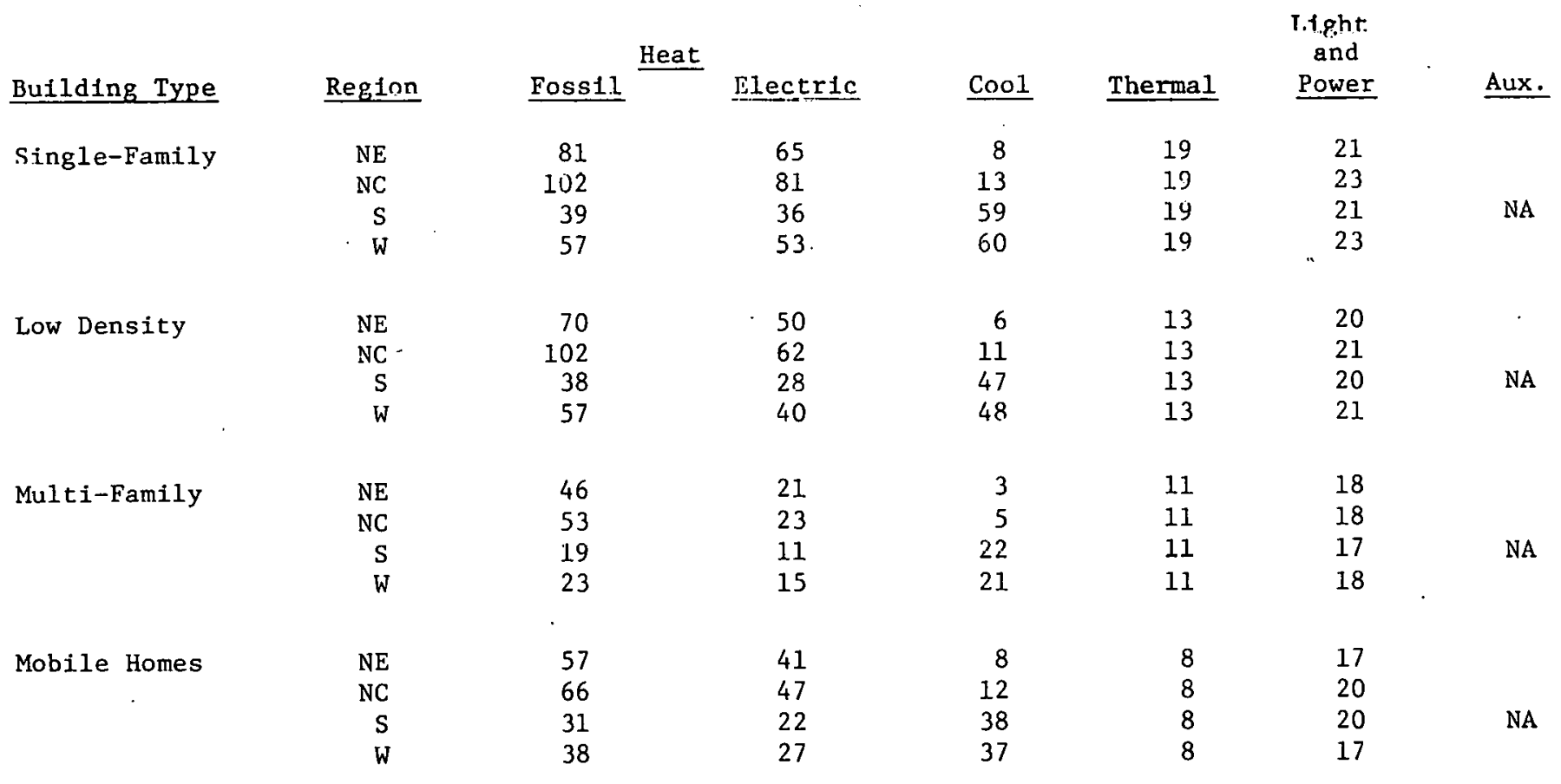

All figures in $10^{6} \mathrm{Btu} / \mathrm{unit}$

Assumes the following conversion efficiencies:

$\begin{array}{ll}\text { Gas } & 0.7 \\ \text { Oil } & 0.6 \\ \text { Electric } & 1.0\end{array}$

A C CoP 2.1 
THEORETICAL BUILDING ENERGY LOADS

COMMERCIAL - NEW CONSTRUCTION 1976-1980

Building Type

Office and Bank

$$
\begin{array}{r}
\text { NE } \\
N C \\
S \\
W
\end{array}
$$

Other

$$
\begin{array}{r}
\text { NE } \\
\text { NC } \\
\text { S } \\
\text { W }
\end{array}
$$

NE

$\mathrm{S}$
Heat Foss11 Electric

\section{4}

51

24

25

NE $\quad 37$

NC

S

$\mathrm{NC}$

W

NE 73

$\mathrm{S}$

22

26

14

16

40

46

18

23

54

54

19

25

24

27

15

16
Light

and

Cool Thermal $\underline{\text { Power }}$

$\begin{array}{ll}24 & 15 \\ 30 & 18 \\ 30 & 20 \\ 31 & 20\end{array}$

25

26

61

40

3
3
3
3

25

\section{9}

19

43

25

60

74

73

86

30
30
35
35

- 2

34

35

37

39

20

25

61.

$--$

All figures in $10^{3} \mathrm{Btu} /$ square foot

Assumes the following conversion efficiencies: $\begin{array}{ll}\text { Gas } & 0.7 \\ \text { Oil } & 0.6 \\ \text { Electric } & 1.0\end{array}$ A C CoP 2.1 
THEORETICAL BUILDING ENERGY LOADS

RESIDENLIAL - II:IROEIT $19 \% 5$ INVWNTORY

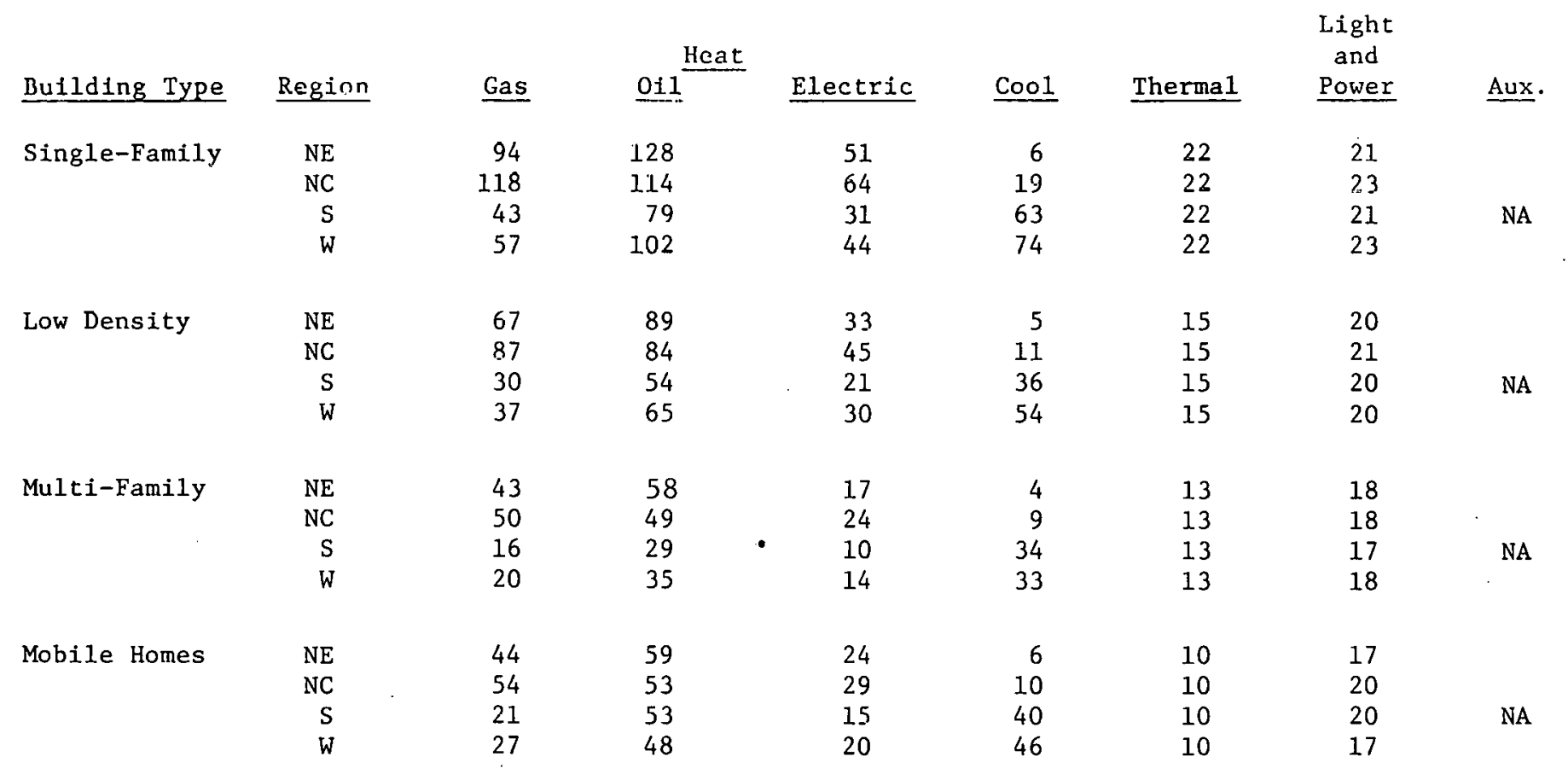

All figures in $10^{6} \mathrm{Btu} /$ unit
Assumes the following conversion efficiencies: Gas $\quad 0.6$


THEORETICAL BUILDING ENERGY LOADS*

COMMERCIAL - RETROFIT 1975 INVENTORY

\begin{tabular}{|c|c|c|c|c|c|c|c|c|}
\hline \multirow[b]{2}{*}{ Building Type } & \multirow[b]{2}{*}{ Region } & - & \multicolumn{2}{|c|}{ Heat } & \multirow[b]{2}{*}{ Cool } & \multicolumn{3}{|c|}{$\begin{array}{c}\text { Light } \\
\text { and }\end{array}$} \\
\hline & & $\underline{\text { Gas }}$ & $\underline{0 i 1}$ & Electric & & Thermal & Power & Aux. \\
\hline \multirow{4}{*}{ Office and Bank } & $\mathrm{NE}$ & 91 & 83 & 31 & 33 & 3 & 24 & 18 \\
\hline & $\mathrm{NC}$ & 84 & 68 & -- & 36 & - & 30 & 20 \\
\hline & $\mathrm{s}$ & 64 & 60 & 19 & 87 & 3 & 30 & 22 \\
\hline & W & 66 & 59 & 20 & 57 & 3 & 31 & 22 \\
\hline \multirow[t]{4}{*}{ Retail } & $\mathrm{NE}$ & 50 & 47 & 14 & 37 & 2 & 62 & 22 \\
\hline & $\mathrm{NC}$ & 46 & 37 & -- & 41 & - & 67 & 27 \\
\hline & $\mathrm{s}$ & 29 & 26 & 10 & 99 & 2 & 69 & 33 \\
\hline & W & 35 & 32 & 13 & 68 & 2 & 72 & 33 \\
\hline \multirow[t]{4}{*}{ Schools } & $\mathrm{NE}$ & 80 & 74 & 28 & 28 & 3 & 26 & 15 \\
\hline & $\mathrm{NC}$ & 74 & 60 & -- & 30 & - & 28 & 18 \\
\hline & $\mathrm{s}$ & 5 & 44 & 14 & 70 & 3 & 28 & 20 \\
\hline & W & 58 & 52 & 19 & 39 & 3 & 31 & 20 \\
\hline \multirow[t]{4}{*}{ Hospitals } & NE & 97 & 89 & 33 & 42 & 16 & 60 & 32 \\
\hline & $\mathrm{NC}$ & 90 & 73 & -- & 45 & -- & 74 & 32 \\
\hline & $\mathrm{s}$ & 55 & 51 & 14 & 106 & 16 & 73 & 37 \\
\hline & W & 68 & 61 & 20 & 76 & 16 & 86 & 37 \\
\hline \multirow[t]{4}{*}{ Other } & NE & 49 & 45 & 16 & 37 & .2 & 34 & 22 \\
\hline & $\mathrm{NC}$ & 46 & 37 & -- & 41 & - & 35 & 27 \\
\hline & $\mathrm{s}$ & 27 & 24 & 11 & 99 & 2 & 37 & 33 \\
\hline & W & 33 & 30 & 13 & 68 & 2 & 39 & 33 \\
\hline
\end{tabular}

All Figures in $10^{3} \mathrm{Btu} /$ square foot

Assumes the following conversion efficiencies:

$\begin{array}{ll}\text { Gas } & 0.6 \\ \text { OiI : } & 0.5 \\ \text { Electric } & 1.0 \\ \text { A C CoP } & 2.1\end{array}$




\section{CONSERVATION TECHNOLOGY CUSTS \& SAVINCS}

BUILDING TYYPE: SINGLE FAMILY 1560 SQ. FT. UNIT

\begin{tabular}{|c|c|c|c|c|c|c|}
\hline & & First Cost & & $\begin{array}{l}\text { RVATION L } \\
\text { of load s }\end{array}$ & & \\
\hline & & S/unit & Heating & Cooling & Hot Water & $\underline{L \& P}$ \\
\hline New Construction & $\mathrm{NE}$ & 220 & 23 & 20 & 5 & 5 \\
\hline & $\mathrm{NC}$ & 220 & 25 & 22 & 5 & 5 \\
\hline & $\mathrm{s}$ & 240 & 23 & 25 & 5 & 5 \\
\hline & W & 240 & 25 & 23 & 5 & 5 \\
\hline Retrofit & $\mathrm{NE}$ & 260 & 15 & 10 & 0 & 0 \\
\hline & NC & 260 & 17 & 10 & 0 & 0 \\
\hline & $\mathrm{s}$ & 200 & 12 & 15 & 0 & 0 \\
\hline & W & 200 & 14 & 13 & 0 & 0 \\
\hline & & & & RVATION LE & II & \\
\hline New Construction & NE & 800 & 50 & 35 & 5 & 5 \\
\hline & $\mathrm{NC}$ & 800 & 52 & 37 & 5 & 5 \\
\hline - & $\mathrm{s}$ & 770 & 44 & 35 & 5 & 5 \\
\hline & $\mathrm{W}$ & 770 & 46 & 33 & 5 & 5 \\
\hline Retrofit & $\mathrm{NE}$ & 1,130 & 43 & 20 & 0 & 0 \\
\hline & NC & 1,130 & 45 & 20 & 0 & 0 \\
\hline & $\mathbf{S}$ & 1,070 & 37 & 25 & 0 & 0 \\
\hline & & & $\mathrm{CON}$ & ATION LEI & II & \\
\hline New Construction & $\mathrm{NE}$ & 2,140 & 58 & 40 & 10 & 5 \\
\hline & NC & 2,140 & 60 & 42 & 10 & 5 \\
\hline & $\mathrm{s}$ & 1,760 & 50 & 40 & 10 & 5 \\
\hline & W & 1,760 & 52 & 38 & 10 & 5 \\
\hline Retrofit & $\mathrm{NE}$ & 1,860 & 52 & 25 & 5 & 0 \\
\hline & $\mathrm{NC}$ & 1,860 & 54 & 25 & 5 & 0 \\
\hline & $\mathrm{s}$ & 1,770 & 44 & 30 & 5 & 0 \\
\hline & W & 1,770 & 46 & 28 & 5 & 0 \\
\hline
\end{tabular}


CONSERVATION TECHNOLOGY COSTS \& SAVINGS

BUILDING TYPE: LOW DENSITY 1000 SQ. FT. UNIT

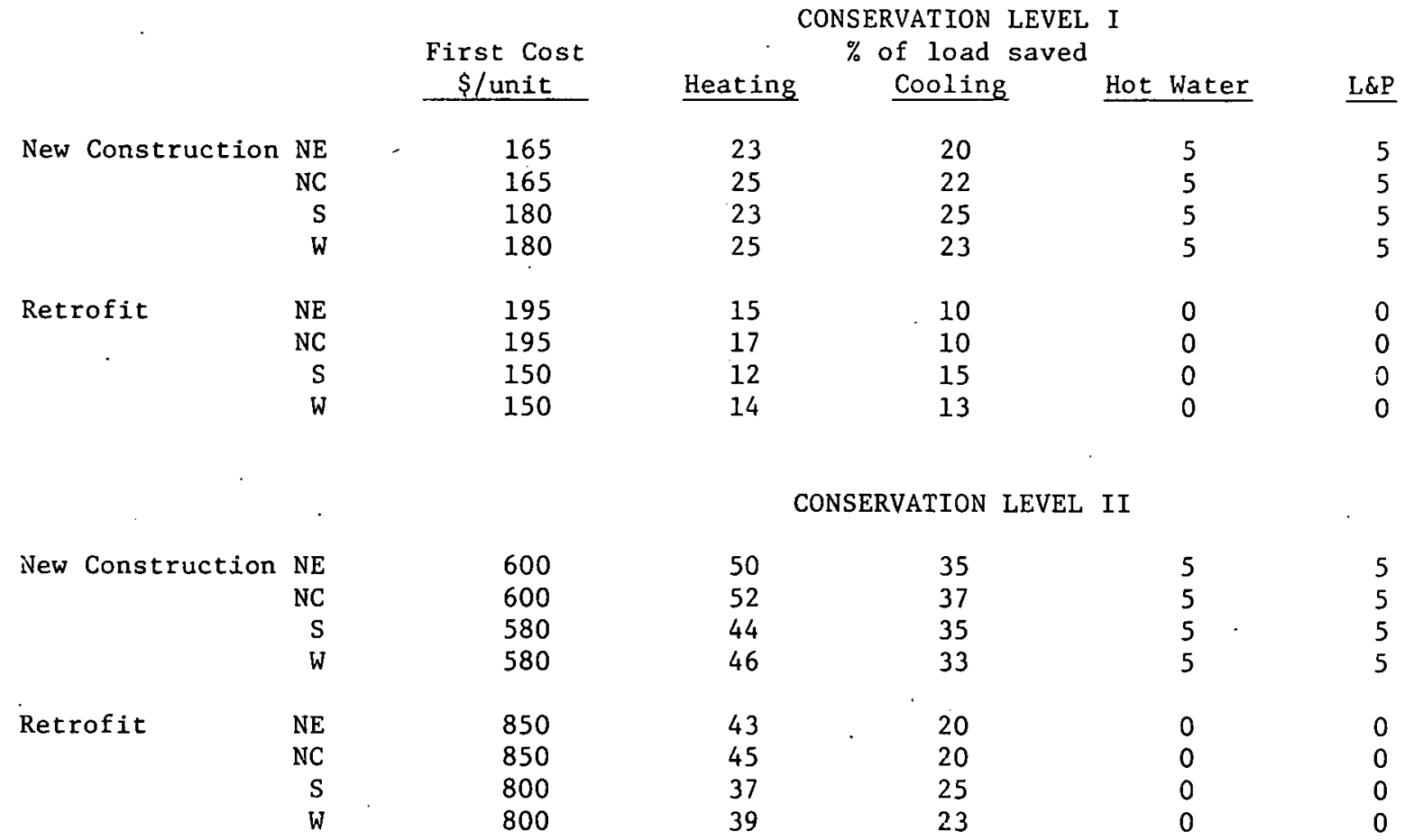

CONSERVATION LEVEL III

$\begin{array}{crc}\text { New Construction } & \text { NE } & 1,600 \\ & \text { NC } & 1,600 \\ \text { S } & 1,320 \\ & \text { W } & 1,320 \\ \text { Retrofit } & \text { NE } & 1,400 \\ & \text { NC } & 1,400 \\ & \text { S } & 1,330 \\ & \text { W } & 1,330\end{array}$

58

60

50

.52

52

54

44

46

\section{0 \\ 42 \\ 40 \\ 38}

25

25

30

28

$\begin{array}{ll}10 & 5 \\ 10 & 5 \\ 10 & 5 \\ 10 & 5\end{array}$

$\begin{array}{ll}5 & 0 \\ 5 & 0 \\ 5 & 0 \\ 5 & 0\end{array}$


CONSERVATION TECHNOLOGY COSTS \& SAVINGS

BUILDING TYPE: MULTI-FAMILY 900 SQ.FT. UNIT

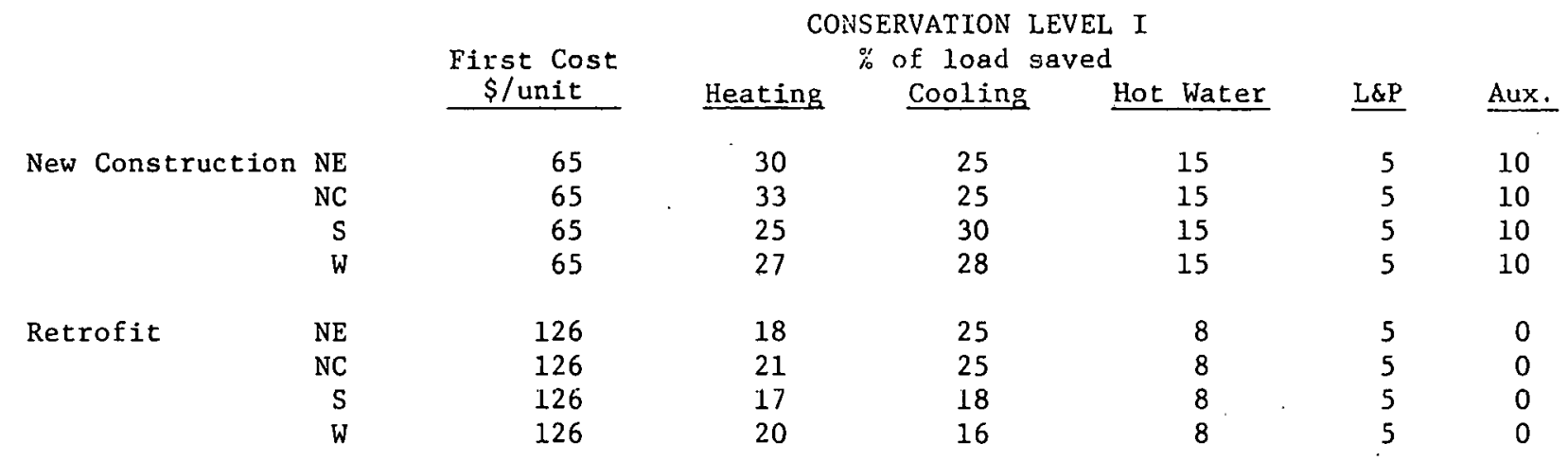

$\begin{array}{rlll}\text { NE } & 120 & 38 \\ \text { NC } & 120 & 4 \\ \text { S } & 120 & & 3 \\ \text { W } & 120 & \\ \text { NE } & 198 & & 24 \\ \text { NC } & 198 & & 28 \\ \text { S } & 198 & & 2 \\ \text { W } & 198 & & 29\end{array}$

CONSERVATION LEVEL II

New Construction

$\begin{array}{ll}38 & 35 \\ 40 & 35 \\ 35 & 42\end{array}$

37

\section{4}

\section{8}

25

29

40

\section{5}

25

22

20

$\begin{array}{lll}15 & 5 & 10 \\ 15 & 5 & 10 \\ 15 & 5 & 10 \\ 15 & 5 & 10\end{array}$

15

15

15

15

CONSERVATION LEVEL III

New Construction N

Retrofit
260

260

260

260

324

324

324

324

45
48
40
42

24

29

25

30
44

44

50

47

25

25

22

18
20

20

20

20

23

23

23

23
510

$5 \quad 10$

510

510


BUILDTNG TYPE: MOBILE HOME 720 SQ. FT. UNIT

\begin{tabular}{|c|c|c|c|c|c|c|}
\hline & & $\begin{array}{l}\text { First Cost } \\
\text { S/unit } \\
\end{array}$ & Heating & $\begin{array}{l}\% \text { of load saved } \\
\text { Cooling }\end{array}$ & Hot Water & $L \& P$ \\
\hline \multirow{4}{*}{ New Construction } & $\mathrm{NE}$ & 1 & 30 & 30 & 5 & 0 \\
\hline & NC & 1 & 30 & 30 & 5 & 0 \\
\hline & $\mathrm{s}$ & 1 & 20 & 20 & 5 & 0 \\
\hline & W & 1 & 20 & 20 & 5 & 0 \\
\hline \multirow[t]{4}{*}{ Retrofit } & $\mathrm{NE}$ & 85 & 15 & 15 & 3 & 0 \\
\hline & $\mathrm{NC}$ & 85 & 15 & 15 & 3 & 0 \\
\hline & $\mathrm{S}$ & 85 & 15 & 15 & 3 & 0 \\
\hline & $\mathrm{W}$ & 85 & 15 & 15 & 3 & 0 \\
\hline
\end{tabular}

CONSERVATION LEVEL II

$\begin{array}{lrr}\text { New Construction } & \text { NE } & 330 \\ & \text { NC } & 330 \\ & \text { S } & 230 \\ & \text { W } & 230 \\ \text { Retrofit } & \text { NE } & 435 \\ & \text { NC } & 435 \\ & \text { S } & 335 \\ \text { W } & 335\end{array}$

30

330

230

30

435

435

335

$\begin{array}{lr}\text { New Construction } & \text { NE } \\ \text { NC } \\ \text { S } \\ \text { Retrofit } & \text { W } \\ & \text { NE } \\ & \text { S } \\ & \text { W }\end{array}$

790

790

490

490

655

655

1,75

475
45
45

30

30

30

30

25

25

CONSERVATION LEVEL III

$\begin{array}{llll}61 & 61 & 7 & 0 \\ 61 & 61 & 7 & 0 \\ 46 & 46 & 7 & 0 \\ 46 & 46 & 7 & 0 \\ 37 & 28 & 7 & 0 \\ 37 & 28 & 7 & 0 \\ 30 & 33 & 7 & 0 \\ 30 & 33 & 7 & 0\end{array}$


CONSERVATION TECHNOLOGY COSTS \& SAVINGS

BUILDING TYPE: OFFICE

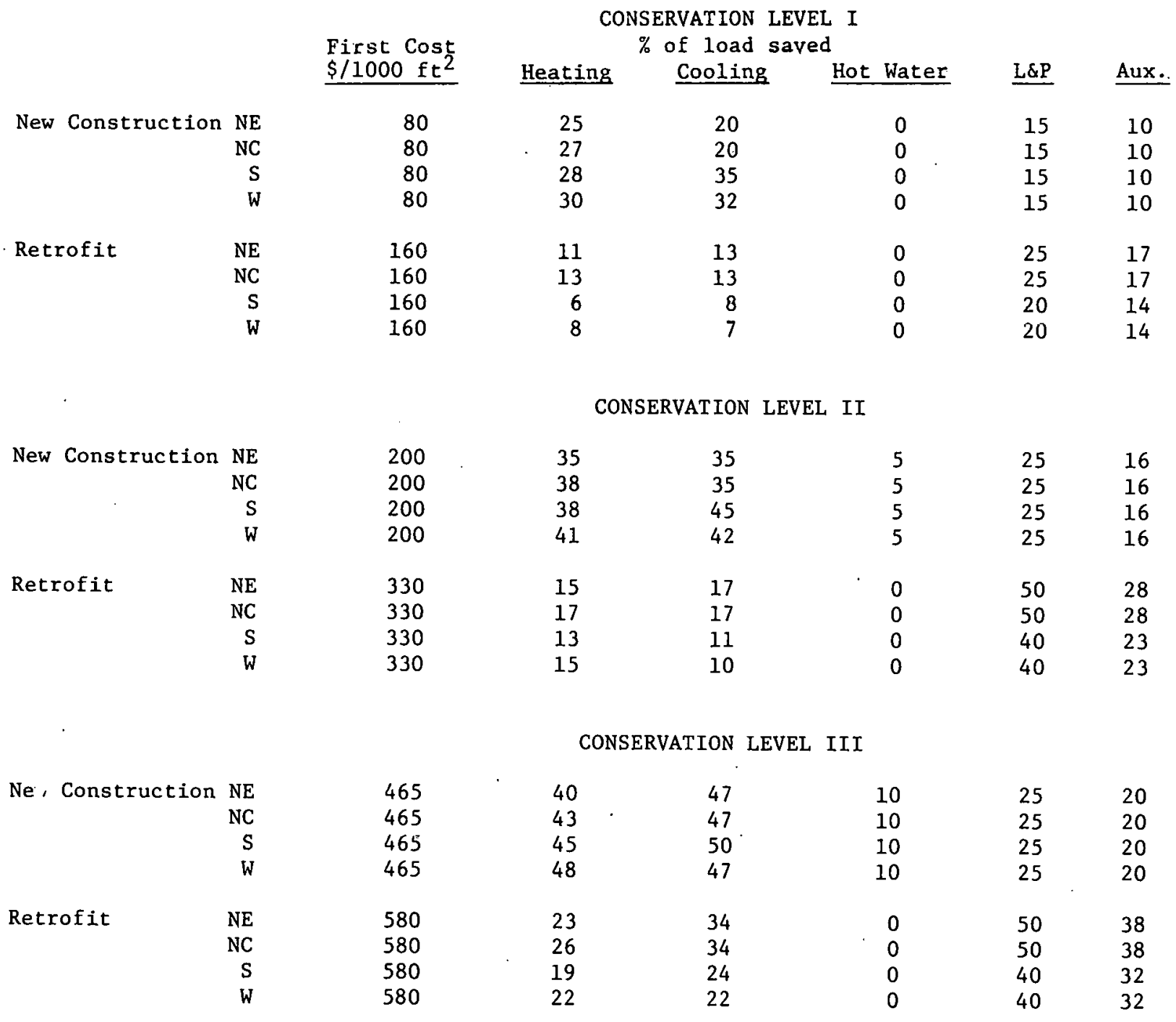


CONSERVATION TECHNOLOGY COSTS \& SAVINGS

BUILDING TYPE: SCHOOL

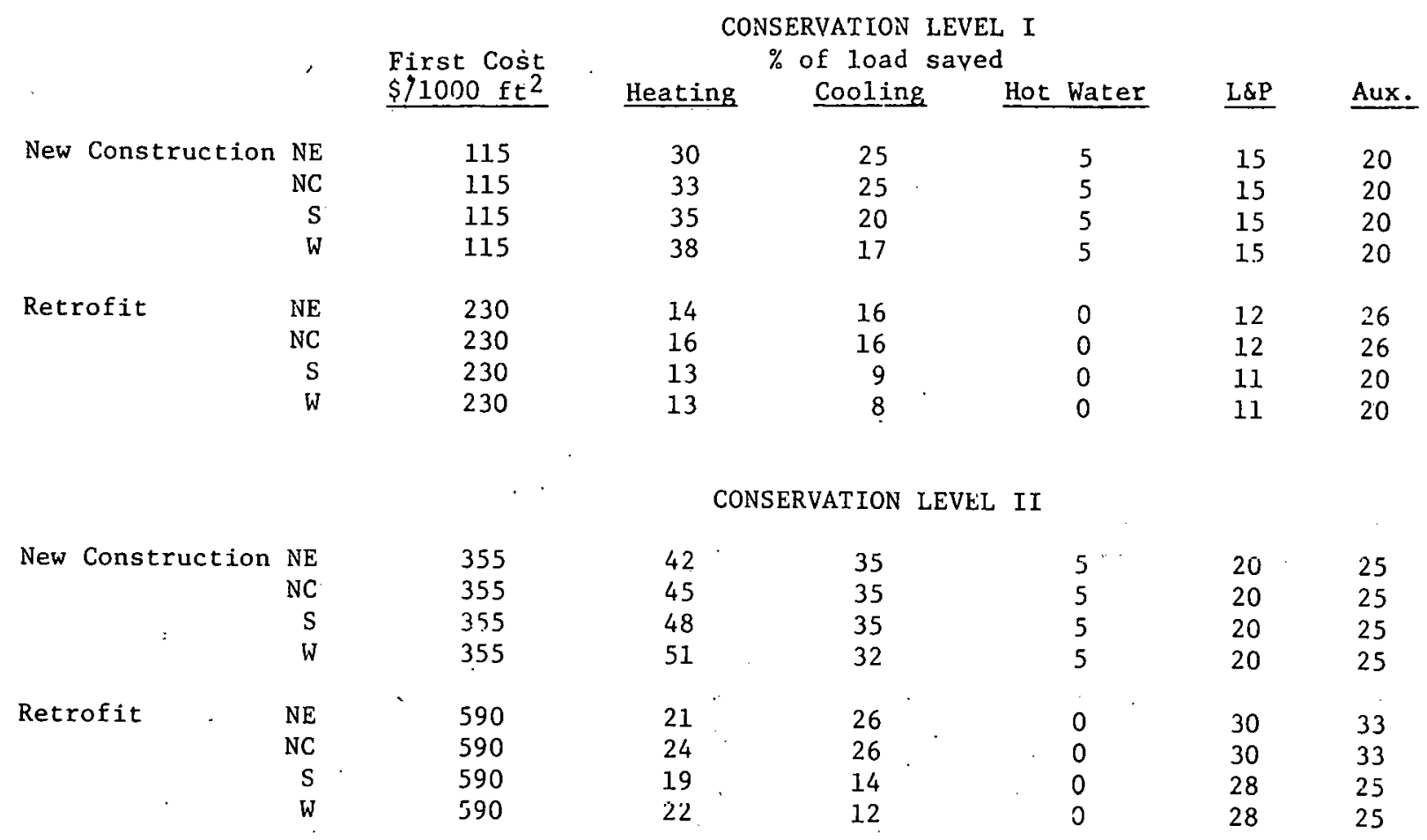

\section{CONSERVATION LEVEL III}

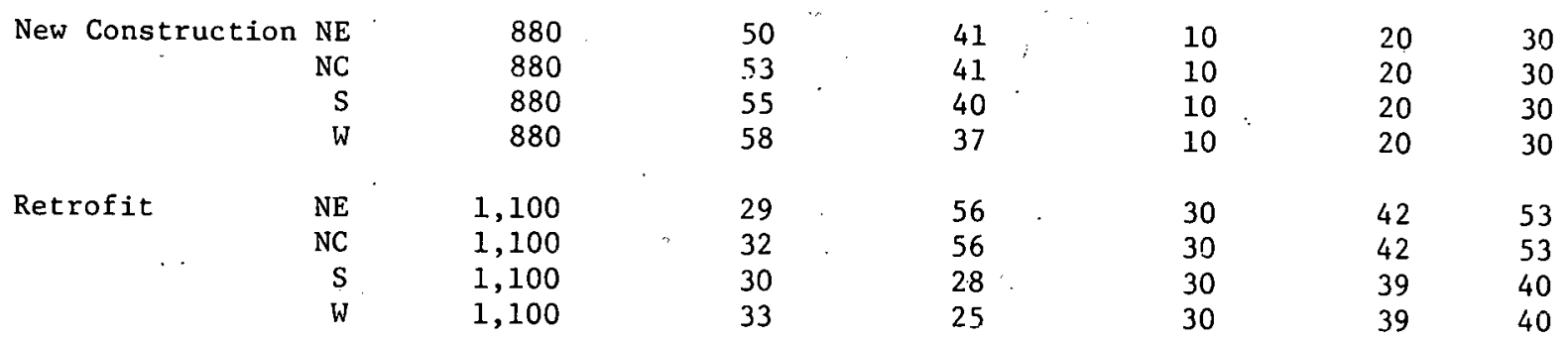


CONSERVATION TECHNOLOGY COSTS $\&$ SAVINGS

BUILDI:G TYYE: HOSPITAL

\begin{tabular}{|c|c|c|c|c|c|c|c|}
\hline 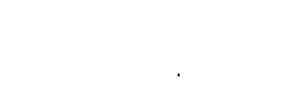 & & First Cost & & $\begin{array}{l}\text { VATION } \\
\text { f load }\end{array}$ & $\begin{array}{l}L \\
d\end{array}$ & & \\
\hline & & $\$ / 1000 \mathrm{ft}^{2}$ & Heating & Cooling & Hot Water & $\underline{L \& P}$ & Aux. \\
\hline New Construction & $\mathrm{NE}$ & 140 & 20 & 15 & 10 & 10 & 10 \\
\hline & $\mathrm{NC}$ & 140 & 23 & 15 & 10 & 10 & 10 \\
\hline & $\mathrm{S}$ & 140 & 20 & 20 & 10 & 10 & 10 \\
\hline & W & 140 & 23 & 17 & 10 & 10 & 10 \\
\hline Retrofit & $\mathrm{NE}$ & 280 & 7 & 7 & 12 & 8 & 19 \\
\hline & NC & 280 & 9 & 7 & 12 & 18 & 19 \\
\hline & $\mathrm{s}$ & 280 & 11 & 8 & 12 & 7 & 16 \\
\hline & & & & VATION I & L IT. & & \\
\hline New Construction & $\mathrm{NE}$ & 455 & 32 & 25 & 15 & 15 & 15 \\
\hline & $\mathrm{NC}$ & 455 & 35 & 25 & 15 & 15 & 15 \\
\hline & $\mathrm{s}$ & 455 & 35 & 30 & 15 & 15 & 15 \\
\hline & $\mathrm{W}$ & 455 & 38 & 27 & 15 & 15 & 15 \\
\hline Retrofit & $\mathrm{NE}$ & 760 & 15 & 24 & 24 & 12 & 25 \\
\hline & $\mathrm{NC}$ & 760 & 18 & 24 & 24 & 12 & 25 \\
\hline & $\mathrm{s}$ & 760 & 23 & 13 & 24 & 10 & 22 \\
\hline & W & 760 & 26 & 11 & 24 & 10 & 22 \\
\hline
\end{tabular}

CONSERVATION LEVEL III

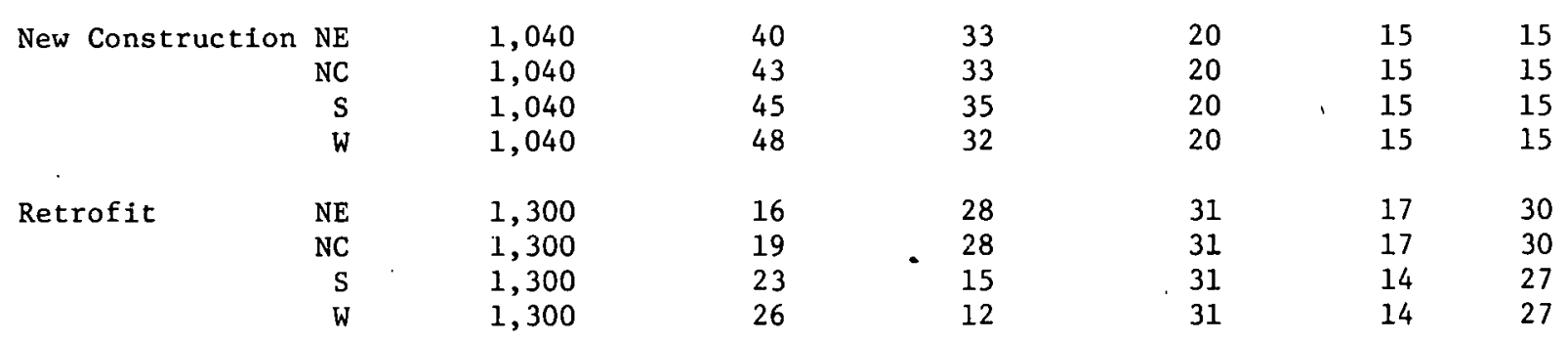


CONSERVATION TECHNOLOGY COSTS \& SAVINGS

BUILDING TYPE: RETAIL STORE

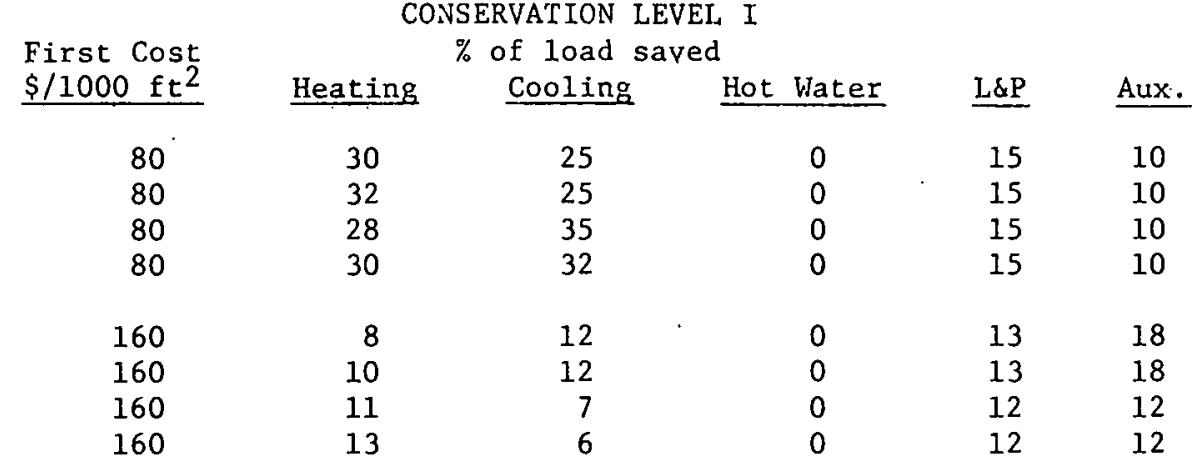

New Construction NE

$\mathrm{NC}$

S

Retrofit

$\begin{array}{rr}\text { NE } & 160 \\ \text { NC } & 160 \\ \text { S } & 160 \\ \text { W } & 160\end{array}$

New Construction NE

NC

S

Retrofit

$\mathrm{NE}$
$\mathrm{NC}$
$\mathrm{S}$
$\mathrm{W}$

175

175

175

175

290

290

290

290

CONSERVATION LEVELL II

$\begin{array}{ll}42 & 37 \\ 45 & 37 \\ 45 & 40 \\ 48 & 37\end{array}$

$\begin{array}{ll}23 & 20 \\ 26 & 20 \\ 25 & 11 \\ 27 & 10\end{array}$

37
37
40
37
20
20
11
10

$\begin{array}{lll}5 & 24 & 16 \\ 5 & 24 & 16 \\ 5 & 24 & 16 \\ 5 & 24 & 16\end{array}$

CONSERVATION LEVEL III

$\begin{array}{rrr}\text { New Construction NE } & 420 \\ \text { NC } & 420 \\ \text { S } & 420 \\ \text { W } & 420\end{array}$

\section{0}

53

55

58

25

28

29

32

46
46
50
45

20
20
13
11

$\begin{array}{lll}10 & 30 & 20 \\ 10 & 30 & 20 \\ 10 & 30 & 20 \\ 10 & 30 & 20\end{array}$

Retrofit

$\begin{array}{rl}\mathrm{NE} & 520 \\ \mathrm{NC} & 520 \\ \mathrm{~S} & 520 \\ \mathrm{~W} & 520\end{array}$

20

13

1.1 .

$\begin{array}{lll}0 & 25 & 45 \\ 0 & 25 & 45 \\ 0 & 23 & 30 \\ 0 & 23 & 30\end{array}$


BUILDING TYPE: MISCELLANEOUS

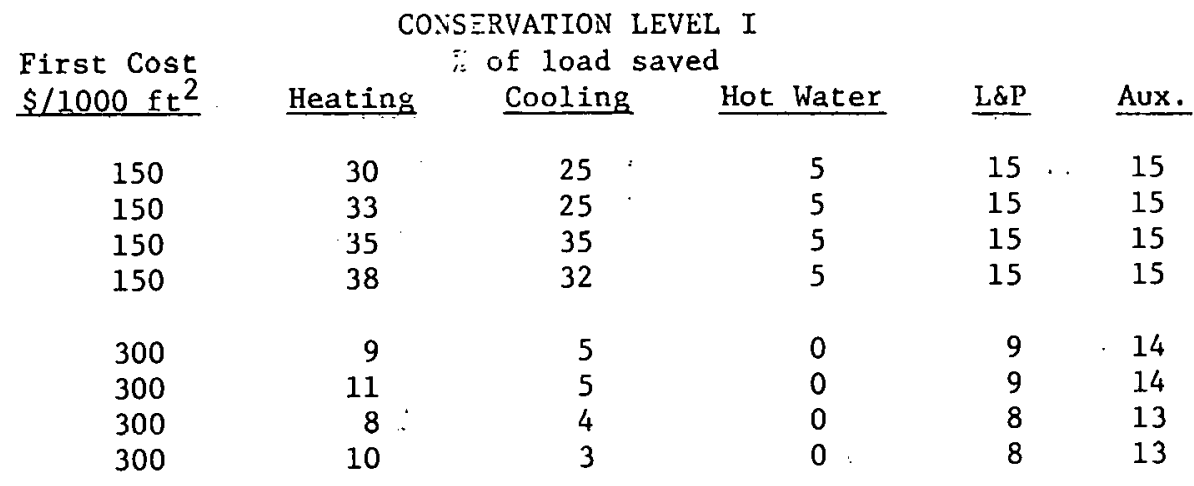

$\begin{array}{lr}\text { New Construction } & \mathrm{NE} \\ & \mathrm{NC} \\ & \mathrm{S} \\ \mathrm{W} \\ & \\ & \mathrm{NE} \\ & \mathrm{NC} \\ & \mathrm{S} \\ & \mathrm{W}\end{array}$

New Construction $\mathrm{NE}$
$\mathrm{NC}$
$\mathrm{S}$
$\mathrm{W}$

Retrofit

$\begin{array}{rr}\text { NE } & 400 \\ \text { NC } & 400 \\ \text { S } & 400 \\ W & 400 \\ & \\ \text { NE } & 660 \\ \text { NC } & 660 \\ \text { S } & 660 \\ W & 660\end{array}$

660

$\begin{array}{rr}\text { NE } & 400 \\ \text { NC } & 400 \\ \text { S } & 400 \\ \text { W } & 400 \\ & \\ \text { NE } & 660 \\ \text { NC } & 660 \\ \text { S } & 660 \\ \text { W } & 660\end{array}$

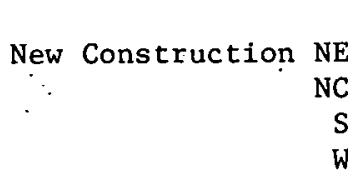

$\begin{aligned} \text { NE } & 1,040 \\ \text { NC } & 1,040 \\ \text { S } & 1,040 \\ \text { W } & 1,040\end{aligned}$

Retrofit

$\begin{array}{rl}\mathrm{NE} & 1,300 \\ \mathrm{NC} . & 1,300 \\ \mathrm{~S} & 1,300 \\ \mathrm{~W} & 1,300\end{array}$

CONSERVATION LEVEL II

$\begin{array}{rrrrr}42 & 35 & 10 & 15 & 20 \\ 45 & 35 & 10 & 15 & 20 \\ 42 & 42 & 10 & 15 & 20 \\ 45 & 39 & 10 & 15 & 20 \\ 15 & 12 & 0 & 15 & 23 \\ 18 & 12 & 0 & 15 & 23 \\ 20 & 7 & 0 & 14 & 23 \\ 23 & 6 & 0 & 14 & 23\end{array}$

CONSERVATION LEVEL III

$\begin{array}{lllll}50 & 40 & 10 & 20 & 20 \\ 53 & 40 & 10 & 20 & 20 \\ 45 & 45 & 10 & 20 & 20 \\ 48 & 42 & 10 & 20 & 20 \\ & & & & \\ 26 & 24 & 0 & 24 & 32 \\ 30 & 24 & 0 & 24 & 32 \\ 40 & 13 & 0 & 22 & 31 \\ 44 & 12 & 0 & 22 & 31\end{array}$


FIRST COSTS OF CONVENTIONAL HVAC EQUIPMENT

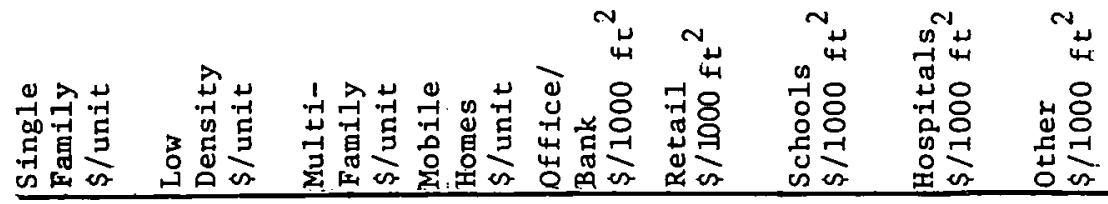

A. Gas Heat

$\mathrm{NE}$
$\mathrm{NC}$
$\mathrm{S}$
$\mathrm{W}$

$\begin{array}{lllllllll}2,980 & 2,650 & 2,322 & 577 & 5,170 & 3,500 & 4,280 & 5,140 & 3,500 \\ 3,073 & 2,750 & 2,412 & 599 & 5,360 & 3,640 & 4,430 & 5,320 & 3,640 \\ 2,730 & 2,410 & 2,115 & 528 & 4,720 & 3,200 & 3,920 & 4,700 & 3,200 \\ 3,073 & 2,750 & 2,412 & 600 & 5,360 & 3,650 & 4,430 & 5,330 & 3,650\end{array}$

B. 011 Heat

$\begin{array}{rlllllllll}\mathrm{NE} & 3,026 & 2,660 & 2,205 & 817 & 5,130 & 3,490 & 4,250 & 5,130 & 3,490 \\ \mathrm{NC} & 3,120 & 2,760 & 2,376 & 848 & 5,320 & 3,630 & 4,400 & 5,310 & 3,630 \\ \mathrm{~S} & 2,777 & 2,320 & 2,088 & 748 & 4,680 & 3,190 & 3,890 & 4,690 & 3,190 \\ \mathrm{~W} & 3,120 & 2,760 & 2,385 & 850 & 5,320 & 3,650 & 4,400 & 5,320 & 3,640\end{array}$

C. Elec. Heat

$\mathrm{NE}$
$\mathrm{NC}$
$\mathrm{S}$
$\mathrm{W}$

$\begin{array}{lllllllll}2,808 & 2,770 & 2,367 & 504 & 5,240 & 3,557 & 4,060 & 5,180 & 3,557 \\ 2,886 & 2,880 & 2,457 & 522 & 5,430 & 3,700 & 4,490 & 5,360 & 3,700 \\ 2,538 & 2,530 & 2,160 & 461 & 4,780 & 3,250 & 3,970 & 4,740 & 3,250 \\ 2,886 & 2,880 & 2,457 & 524 & 5,430 & 3,710 & 4,490 & 5,370 & 3,710\end{array}$

D. Gas Heat W/AC

$\mathrm{NE}$
$\mathrm{NC}$
$\mathrm{S}$
$\mathrm{W}$

$\begin{array}{llll}4,705 & 3,239 & 3,780 & 1,978\end{array}$

$4,682 \quad 3,360 \quad 3,870 \quad 2,051$

8,940

5,940

$7,720 \quad 14,667 \quad 5,940$

4,308

9,150

6,080

$7,60013,500 \quad 6,080$

$4,866 \quad 3,362 \quad 3,888 \quad 2,056$

8,610

5,730

$7,14011,900 \quad 5,730$

$6,095 \quad 7,62013,520 \quad 6,095$

E. Oil Heat W/AC

$\mathrm{NE}$
$\mathrm{NC}$
$\mathrm{S}$
$\mathrm{W}$

$4,751 \quad 3,249$

$4,909 \quad 3,370$

$3,6632,218$

$3,834 \quad 2,301$

8,900

9,110

5,930

$7,690 \quad 14,657 \quad 5,930$

$4,355 \quad 2,859$

$3,6092,029$

8,570

6,069

$7,570 \quad 13,490 \quad 6,069$

$4,913 \quad 3,372$

$3,8612,305$

9,140

5,720

$7,110 \quad 11,890 \quad 5,720$

F. Elec. Heat W/AC

$\mathrm{NE}$
$\mathrm{NC}$
$\mathrm{S}$
$\mathrm{W}$

4,533

3,359

$3,825 \quad 1,905$

9,010

6,085

$7,590 \quad 13,510 \quad 6,085$

$4,675 \quad 3,490 \quad 3,915 \quad 1,976$

4,136

4,679

3,069

$3,681 \quad 1,743$

9,220

6,000

$7,500 \quad 13,040 \quad 6,000$

8,670

6,140

$7,66013,540 \quad 6,140$

3,492

$3,9331,980$

9,250

5,780

$7,190 \quad 11,940 \quad 5,780$

G. Elec. Heat Pump

$\mathrm{NE}$
$\mathrm{NC}$
$\mathrm{S}$
$\mathrm{W}$

$\begin{array}{ll}4,833 & 3,654 \\ 5,125 & 3,790 \\ 4,436 & 3,219 \\ 5,129 & 3,642\end{array}$

$3,975 \quad 2,205$

$4,065 \quad 2,276$

9,310

6,150

9,520

6,290

$7,68013,560$

6,170

H. Gas Heat Pump

NE
NC
$S$
$W$

$$
\begin{array}{ll}
6,725 & 4,965 \\
7,275 & 5,110 \\
5,890 & 4,260 \\
6,920 & 5,115
\end{array}
$$

$3,8312,143$

8,970

5,930

$7,800 \quad 13,040 \quad 6,15 \mathrm{C}$

$4,083 \quad 2,280$

9,550

6,320

$7,96013,840 \quad 6,290$

$7,490 \quad 12,390 \quad 5,930$

$7,98013,8606,320$

$5,255 \quad 2,735 \quad 11,810$

$7,850 \quad 10,345 \quad 18,680 \quad 7,850$

$5,375 \quad 2,820 \quad 12,060$

$8,015 \quad 10,20017,280 \quad 8,015$

$\begin{array}{lll}4,725 & 2,890 & 11,050 \\ 5,025 & 3,190 & 11,735\end{array}$

$7,595 \quad 9,290 \quad 15,000 \quad 7,595$

$8,0359,865 \quad 16,945 \quad 8,035$ 